\title{
La indumentaria tradicional en la construcción de la identidad extremeña
}

\author{
Traditional Clothing in the Construction \\ of the Extremenian Identity
}

\author{
Juan M. Valadés Sierra \\ Museo de Cáceres
}

\section{RESUMEN}

En el proceso de etnogénesis de la comunidad extremeña, los símbolos regionales desempeñan un papel fundamental, tanto en la creación de iconos nuevos como en la selección y actualización de elementos tradicionales, entre los que no faltan los originados en tradiciones inventadas. La indumentaria es uno de esos símbolos de la región, habiendo llegado a constituirse un modelo, el traje de Montehermoso, aceptado como representativo de la comunidad, junto a modelos emblemáticos de algunas localidades donde en realidad la indumentaria tradicional se había perdido hace ya cien años.

Palabras clave: Extremadura, Etnicidad, Símbolos, Traje Regional, Trajes Populares, Sorolla, Ortiz Echagüe.

\section{SUMMARY}

In the ethnogenesis process of the region of Extremadura, the regional symbols play a key role both in creating new icons and the selection and updating of traditional elements, including some originated in invented traditions. Clothing is one of those symbols of the region, having become a model, Montehermoso dress, accepted as representative of the community, beside iconic models in some locations where traditional clothing was already lost one hundred years ago.

Key words: Extremadura, Ethnicity, Symbols, Regional Dress, Folk Costumes, Sorolla, Ortiz Echagüe.

Los extremeños responsables de todas las categorias sociales aprecian su berencia, para todos ellos el traje local es una expresión de la identidad singular de su localidad de origen, y más allá de ello, del especial carácter de la propia Extremadura.

(Ruth Matilda Anderson 1951: 319)

Hace ya unos años, estudiando el proceso de institucionalización de la gorra de paja que lleva la mujer en el traje tradicional de Montehermoso, señalamos que en 
realidad, tanto su uso con el traje de gala, como la gran antigüedad que se le ha venido atribuyendo ("del tiempo de los moros", se decía antes; "legado de los celtas", se puede leer en Internet) e incluso la explicación sobre el uso diferenciado de la gorra según el estado civil (con espejo la soltera, con espejo roto la casada y sin espejo la viuda) eran en realidad parte de una tradición inventada (Valadés 1994). Lo cierto es que el invento funcionó, porque esas supuestas particularidades han llevado a que el traje de Montehermoso sea considerado como la representación genuina del traje de Extremadura, y en la actualidad, varias generaciones después de aquella invención erudita, la leyenda del espejo, la antigüedad de la gorra y su presencia en el traje de gala montehermoseño son indiscutidos por una gran parte de la población, no sólo de la localidad cacereña, sino sobre todo y mucho más por los foráneos.

El sentido de la tradición inventada es, sin duda, contribuir a reforzar los lazos de identidad de un grupo; se trata de utilizar elementos del pasado, de un pasado glorioso o mejor que el presente, para dar sentido a la actualidad, renovando la pertenencia a ese grupo heredero de aquellos grandes antepasados (Hobsbawm 2002). El caso de Montehermoso afecta a toda la región extremeña, dado que ha adquirido capacidad de representación supracomunal, pero la indumentaria que se considera tradicional ha sufrido casi en todas partes un proceso similar en la escala local; así, se conservan y se recuperan trajes de todos los pueblos donde es posible, como parte del rescate de la memoria de la comunidad, y se consideran un símbolo del propio colectivo que se resiste a ver diluida su identidad en estos tiempos de globalización. Así, este texto se dedica a analizar este proceso de asimilación e interiorización de la indumentaria tradicional como uno de los símbolos reconocidos localmente, pero también en la escala supracomunal, para la construcción de la identidad regional en el caso de Extremadura.

\section{SOBRE LA IDENTIDAD EXTREMEÑA Y SUS SÍMBOLOS}

Es en el último cuarto del siglo XX cuando se forja en Extremadura, impulsada por los nuevos poderes públicos regionales, la conciencia de ser y pertenecer a una entidad regional diferenciada, con una personalidad propia y distinta de otras comunidades españolas. Esto ha sido posible en primer lugar por la promulgación de un Estatuto de Autonomía, a la que Extremadura accedió por la vía lenta del artículo 143 de la Constitución de 1978, y posteriormente por la creación por parte del gobierno regional, la Junta de Extremadura, de diferentes programas educativos - entre los que destaca el Programa de cultura extremeña (González, Sierra y Esteban 2002), que de algún modo vino a suplir el vacío dejado por la desaparecida Semana de Extremadura en la escuela, creada en 1977 por iniciativa del ICE de la Universidad de Extremadura (Blázquez y Maya 1992) - y de la organización de un corpus de símbolos de la región, desde los llamados emblemas institucionales, como el escudo o la bandera, hasta la elección de la fiesta oficial de la Comunidad Autónoma.

El sentimiento regional empezó siendo un anhelo de numerosas personas y colectivos que aspiraban a un cambio sustancial en aspectos clave como el reparto de la riqueza agraria o la posición subalterna de Extremadura dentro del estado español; la región había sido calificada con demasiada frecuencia como una colonia in- 
terna del poder central (Gaviria, Naredo y Serna 1978). Progresivamente, la afirmación de la identidad regional fue normalizándose y si todavía en 1988 se organizaban foros de discusión sobre el alcance de la misma (VV. AA. 1988), el sentimiento ha ido calando en las nuevas generaciones y hoy la personalidad regional de Extremadura ha dejado de ser tema de discusión para convertirse más bien en objeto de estudio (Calvo 1996; Marcos 1998).

Es sabido que un grupo étnico es una comunidad que se autoperpetúa biológicamente, comparte valores culturales fundamentales, integra un campo de comunicación e interacción y, sobre todo, cuyos miembros se identifican a sí mismos y son identificados por otros como una categoría distinguible (Barth 1976: 11). La identidad supone un modo de ser particular, una manera específica de cohesión colectiva, pero la etnicidad, como desarrollo de esa identidad, es un proceso continuo de referencias individuales y grupales respecto a otros individuos y grupos étnicos diferentes (Esteva 1984: 29). Es decir, que la identidad étnica se sustenta en la consciencia de la diferencia y del contraste con los otros (Pujadas 1993: 12). No sólo se tiene conciencia de lo que se es, sino sobre todo de lo que no se es. Para algunos autores, como Isidoro Moreno (2008: 187), la etnicidad existe como hecho objetivo del que pueden tener o no conciencia los sujetos participantes, de manera que podemos aceptar que la identidad étnica no deja de ser una construcción cultural basada en la diferencia, que tiene componentes objetivos, como pueden ser la lengua, el territorio, la historia o las instituciones y proyectos sociales, económicos y jurídicos, pero que también incluye esenciales elementos subjetivos, donde entran en juego, entre otros, la autoidentificación, la tradición, los sentimientos y afectos, los valores adquiridos, las vivencias personales, los mitos, los rituales y los símbolos ${ }^{1}$.

La identidad étnica viene dada, pues, por la autoidentificación de los miembros del grupo (cómo nos vemos) y al mismo tiempo por la identificación que se hace desde fuera del grupo (cómo nos ven), pero no es una noción estática, sino que cambia con el tiempo, se manipula, redefine y adapta en cada contexto (Marcos 1998: 4). La reafirmación de esa personalidad social requiere de una activación o utilización de los símbolos que puede suponer, como en el caso extremeño, la construcción de la identidad, la etnogénesis, desde dentro y desde fuera de la región a través de procesos dialécticos y conflictivos de interrelaciones asimétricas (Calvo 1993: 325). Un mecanismo de esta utilización simbólica, y no sólo en comunidades como Extremadura que buscan elementos diferenciadores para sustentar su identidad, es lo que se ha dado en llamar la invención de la tradición, un proceso asociado a la creación o re-creación de símbolos grupales que, caracterizados por la referencia al pasado, utiliza materiales antiguos para construir tradiciones inventadas de género nuevo y para propósitos nuevos (Hobsbawm 2002: 12).

La identidad étnica se apoya en bases culturales compartidas que identifican a la

\footnotetext{
${ }^{1}$ El símbolo es una convención, mediante la cual una imagen puede representar una idea sin que exista una relación intrínseca entre ambas; esta asociación es arbitraria, pero su aceptación social hace posible el funcionamiento de los símbolos, ya sean materiales o inmateriales, verbales, pictóricos, literarios, gestuales, etc. (Leach 1981: 15-22). Por su parte, Clifford Geertz (2004: 144-145) ve los símbolos como vehículos de significado, que desempeñan un importante papel en la vida social el cual les viene dado por el uso, hasta el punto de considerar la cultura como un sistema dinámico de símbolos.
} 
comunidad; estos marcadores identitarios adquieren el carácter de símbolos capaces de aglutinar la representación subjetiva del grupo humano; por lo general se refieren al pasado, bien sean hechos o estructuras históricas, o bien se trate de tradiciones inventadas. En general el papel de estos símbolos, heredados o creados ex novo, es el de vehicular la cohesión social, legitimar instituciones o relaciones de autoridad e inculcar valores y creencias o convenciones relacionadas con el comportamiento (Hobsbawm 2002: 16); entre ellos se encuentran elementos culturales como el territorio, la lengua, la religión, las cosmogonías y mitologías, los iconos, banderas, escudos, himnos, modos de vida, usos jurídicos o el folklore.

En el caso de Extremadura, la implantación de la autonomía regional supuso la introducción de unos símbolos nuevos, como la bandera, el escudo y el himno, que a falta de una existencia anterior, utilizaron elementos históricos o míticos, como las referencias a la conquista de América, los reinos de Castilla y León, e incluso al reino taifa de Badajoz. De estos tres emblemas, sólo la bandera ha seguido una trayectoria de abajo hacia arriba, ya que no fue creada por los nuevos poderes autonómicos, sino aceptada e incorporada al Estatuto de 1983 una vez que se propuso por numerosos colectivos que venían utilizándola desde 1976 (Rodríguez Contreras 1993). Tal vez por ello, y por su visibilidad en edificios y documentos oficiales, puede considerarse el único de estos nuevos símbolos que ha sido interiorizado por una mayoría de los extremeños, o al menos el que lo ha hecho en mayor grado. El escudo y el himno autonómicos, por otra parte, fueron introducidos por la Ley de 3 de Junio de 1985 (DOE 2-IX-1985) previo encargo por parte del parlamento regional, y es significativo que el propio preámbulo de la ley reconozca que se buscaban

unos símbolos que [...] identifiquen al pueblo extremeño y contribuyan tanto al desarrollo del sentimiento autonómico y regional ${ }^{2}$ como a la integración del mismo en el marco político de la Comunidad Autónoma de Extremadura.

En la actualidad gozan de una aceptación mucho menor; pocos son los extremeños que saben describir el escudo y razonar su simbología, y apenas una minoría de los residentes en la región es capaz de cantar el himno sin leer la letra.

En la misma Ley de 1985 se aprueba también la fiesta oficial de la comunidad: el Día de Extremadura, que con toda intención se hizo coincidir en el 8 de septiembre con la festividad de la Virgen de Guadalupe. A decir verdad, diversos colectivos extremeños ya habían elegido esta fecha como día de celebración supracomunal de la etnicidad regional fuera de Extremadura; en lugares como Leganés se venía celebrando desde 1981, cuatro años antes del primer Día oficial de Extremadura que organizó el gobierno regional en la propia puebla de Guadalupe (Valadés 1995: 48). La celebración oficial del día de la región ha elegido el icono religioso por excelencia, la Patrona de la comunidad, así declarada desde 1907, dándose en este caso una coincidencia entre lo oficial y lo popular, es decir, que la identificación de la comunidad con su icono religioso (símbolo comunal), que puede localizarse prácticamente en cada pueblo extremeño con respecto a su santo o virgen patrona, pasa a ser, en un nuevo contexto de diferenciación como grupo étnico, una identificación con el símbolo supracomunal guadalupano que es incorporado al repertorio simbólico oficial.

\footnotetext{
${ }^{2}$ El énfasis es nuestro.
} 
Entre los otros elementos que se eligen como referentes comunitarios, se puede señalar la lengua. En esta cuestión, volvemos a encontrar el debate acerca de la existencia o no de un dialecto extremeño. Frente a la aceptada existencia del extremeño o español de Extremadura (Montero 2006: 10-11), no deja de ser significativa la diversidad interna de esa realidad, pudiendo detectarse un habla altoextremeña y otra bajoextremeña, pero también hablas portuguesas en lugares limítrofes como Cedillo, Herrera de Alcántara, aldeas de Valencia de Alcántara o el área de La Codosera y Olivenza, y, desde luego, el habla del grupo galaico-portugués que constituye la fala, propia del Valle del Jálama, al noroeste de la provincia de Cáceres, que además en 2001 fue declarada Bien de Interés Cultural por la Junta de Extremadura. Por todo ello, en el caso extremeño la lengua puede considerarse como símbolo de una mayoría de la comunidad — al estilo de la frase de Chamizo, "quien no diga jacha, jigo, jiguera no es de mi tierra $\Longleftarrow$, pero no de toda ella, por encerrar una significativa variedad interna y al mismo tiempo mostrar una escasa diferenciación con el habla castellana del entorno que rodea a la región.

Entre los restantes elementos culturales importantes por su peculiaridad, acaso el más significativo sea el Fuero de Baylío, único aspecto citado individualmente en el Estatuto de Autonomía como valor cultural que debe ser protegido, junto a las "demás instituciones de Derecho consuetudinario". Sin embargo, esta particularidad extremeña del régimen económico matrimonial, consistente en la comunicación de todos los bienes aportados por los desposados y en la posterior partición por mitad al liquidarse la sociedad conyugal, no sólo afecta a una limitada zona de la provincia de Badajoz (Villalba 2009), sino que además es prácticamente desconocida para la mayor parte de la población fuera de esa área.

No debe olvidarse tampoco la significación para la identidad de la región de la aventura americana (Calvo 1996: 60-65), sometida a actualización y reinterpretación desde las celebraciones del V Centenario en 1992. El papel desempeñado por esta colonia interna en la conquista, evangelización y colonización del Nuevo Mundo es fundamental en la autoidentificación de los extremeños, antaño a partir de la perspectiva épica del conquistador, y centrada ahora más en el papel desarrollado por los millares de emigrantes que viajaron a América para construir un nuevo mundo mejor que el que abandonaban en la vieja península ibérica. Íntimamente vinculado a éste, otro símbolo de la identidad extremeña es la emigración durante los años de la reconstrucción europea tras la Segunda Guerra Mundial y el desarrollismo español de los años sesenta y setenta del siglo pasado; el hecho de que casi la mitad de los extremeños tuvieran que abandonar su tierra en esas décadas como consecuencia de la postración en que se encontraban, y que esos emigrantes hayan sido la vanguardia de la recuperación de la dignidad e identidad regional a través de la convivencia con otros grupos y su consiguiente afirmación étnica (Valadés 1996: 170; Marcos 1998: 7) es algo que está presente y cobra protagonismo en el repertorio simbólico de la región, en gran parte como reivindicación del papel de una periferia sin peso en el Estado que ha sido injustamente marginada y utilizada como mano de obra barata y que reclama "no ser menos que nadie".

Entre los elementos culturales susceptibles de convertirse en símbolos de la región restan por considerar aquellos que forman "el acervo de las costumbres y tradiciones populares" a que se refiere el estatuto autonómico; ese legado ha sido 
desentumecido y reactualizado, desempolvado y reabrillantado (Calvo 1993: 321) en este proceso de construcción de la identidad; se utilizan la literatura, la música y la danza, la gastronomía, las formas de habitación, las artesanías, las fiestas o los modos de vida (Marcos y Guío 1996) y, por supuesto, la indumentaria llamada tradicional a la que nos vamos a referir.

\section{EL TRAJE REGIONAL Y LA INDUMENTARIA TRADICIONAL EXTREMEÑA}

En realidad, para referirse a la indumentaria tradicional en Extremadura, como debe suceder en otras latitudes, conviene matizar como punto de partida la diferencia que existe entre lo que habitualmente se considera el traje regional y lo que realmente ha sido la indumentaria tradicional confeccionada y utilizada por la generalidad de la población a lo largo de los últimos trescientos años. El llamado traje regional es un estereotipo, un modelo institucionalizado, aunque ya interiorizado por generaciones que lo consideran un símbolo, y responde a la fosilización de una forma de vestir particularmente lujosa o distintiva que, en ninguna parte parece anterior a los años finales del siglo XVIII (Thiesse 2001: 194), y que parece haber quedado fijada antes de las transformaciones económicas y sociales del último tercio del siglo XIX (Hoyos y Hoyos 1947: 158), pero en realidad no representa la manera en que la mayoría de la gente vestía cada día en las localidades que el traje regional pretende representar. Este proceso de simplificación, uniformización y simbolización no debe considerarse moderno ni achacarse exclusivamente a los grupos folklóricos ni a los Coros y Danzas de la Sección Femenina de Falange, sino que sus orígenes se remontan a la segunda mitad del siglo XVIII cuando, partiendo de los disfraces de carnaval utilizados por la burguesía, se popularizan las representaciones de los tipos populares que identifican a las provincias españolas. Los frescos de Tiépolo en el Salón de Reinos del Palacio Real de Madrid, representando esta variedad de tipos, y las sucesivas series de estampas que aparecen en el mercado durante el reinado de Fernando VII van fijando la imagen del traje regional como reliquia de un pasado castizo frente al empuje de la modernización de orígenes foráneos (Vega 2005: 71). Este proceso continuará durante todo el siglo XIX e inicios del siguiente a través de estampas y colecciones fotográficas de tipos populares, como la comercializada por la casa J. Laurent y Cía., y fundamentalmente a partir de la crisis del 98, cuando se quieren encontrar en el sencillo pueblo español los valores positivos fundamentales para la regeneración del país, expresados plásticamente por la determinante serie de obras de Sorolla realizada para la Hispanic Society of America y finalizada en 1919 (Anderson 1957). La organización de la Exposición del Traje Regional de 1925, dirigida por Luis de Hoyos con la colaboración de sus alumnas del Seminario de Etnografía, Folklore y Artes Populares de la Escuela Superior del Magisterio (Ortiz 1987: 73-74), así como otras publicaciones posteriores, entre las que destacan los extraordinarios trabajos fotográficos de José Ortiz Echagüe, terminan por fijar los modelos regionales que, no lo olvidemos, han continuado y continúan todavía hoy en evolución. En el caso extremeño, más que la creación de un traje regional (aunque también), se dio la generación de los correspondientes a las dos provincias, modelos ya asumidos y utilizados hasta la saciedad, que han experimentado una revitalización especial desde el inicio del 
proceso autonómico, convirtiéndose en un icono más de la extremeñidad y en un símbolo en el proceso de etnogénesis o construcción de la identidad a que nos hemos referido.

En el concepto de traje regional hemos de incluir también los llamados trajes populares, que son los modelos indumentarios locales que sirvieron de base para la creación del estereotipo provincial o regional. Esos modelos locales tampoco reflejan la manera real en que vestían las personas hace cien o doscientos años, sobre todo por la uniformización que representan y la congelación del modelo en un momento indeterminado, pero se han asentado en la costumbre y ya forman parte del repertorio icónico y simbólico destinado a reforzar la cohesión social mediante la manipulación de un elemento supuestamente histórico y creado por el pueblo. Esto no quiere decir que el traje popular haya sido inventado ex novo, muy al contrario parte de raíces que efectivamente son antiguas, incorporando prendas ya conocidas en el siglo XVIII, e incluso antes, y supone una particularización del modo de vestir de cada localidad, distinguible en algunos casos del usual en otras poblaciones, que parece declinar en el siglo XIX por el empuje de las modas urbanas, quedando también fosilizado y reservado para ceremonias y días festivos (González Mena 1990: 76), y desapareciendo de muchos lugares por completo desde comienzos del siglo XX. El traje popular es en realidad otro estereotipo, de rango local, que queda estandarizado sin representar la variedad socioeconómica, laboral o ritual de cada lugar. El cambio en las formas de vestir que se impone en las ciudades y pueblos extremeños durante el primer tercio del siglo pasado, incorporando unos gustos más urbanos, relega al olvido y al arcón, en el mejor de los casos, numerosas prendas de vestir heredadas o que respondían a épocas pasadas y que hasta entonces seguían siendo de uso cotidiano. La guerra civil trajo, además de una aceleración en este proceso, la amortización de muchas de esas prendas, saqueadas por las tropas que iban ocupando los pueblos de Extremadura o vendidas por sus propietarios para poder comer; así se perdió una gran parte del legado de varias generaciones, conservándose sólo parcialmente las muestras de lo que había sido el traje popular o usual ochenta o cien años atrás. Dado que las familias trataron de conservar las prendas de más lujo, propias de celebraciones y días festivos, parece que fueron estos elementos los que se utilizaron desde los años cuarenta del siglo pasado para la recuperación de los trajes populares por parte de la Sección Femenina de FET y de las JONS en su intento por "desentrañar, salvar, revitalizar lo auténticamente Español para edificar sobre ello el futuro de la Patria" (Sampelayo 1969: 99); un proyecto caracterizado por la elección de un modelo de traje por provincia, además de un número reducido de ellos en cada provincia como repertorio indumental de los grupos de Coros y Danzas de las capitales. En estos modelos, las prendas se alteran, modifican o inventan, se generaliza la tendencia a acortar los refajos, se adulteran telas y tejidos, proliferan los adornos, se simplifican los trajes para facilitar los bailes y no se duda en utilizar prendas de otros trajes foráneos cuando se carece de las autóctonas (Sánchez Franco 2008: 62; Ortiz 2012: 14).

Frente a ese traje regional y sus versiones locales, estereotipos ya asumidos como parte del patrimonio cultural de la región, debemos referirnos a la indumentaria que se ha utilizado en Extremadura tradicionalmente, es decir, desde finales del Antiguo Régimen y residualmente hasta hace unas pocas décadas —según lugares, edades y 
clases sociales - teniendo en cuenta como base del concepto tradicional que éste de ningún modo se refiere a una sociedad estática, sincrónica y aislada, sino sujeta a la evolución y los cambios que afectan a todo grupo humano (Arnhold 1986: 49-50) y, sobre todo, que la tradición no deja de ser una construcción social que actualiza y renueva el legado del pasado desde el presente, y por lo tanto es dinámica, cambiante y adaptativa (Marcos 2008: 284-287). Esas formas de vestir, de las que podían rastrearse hasta no hace mucho sus últimos vestigios, son las que en su día dieron lugar a los citados trajes populares, pero no se limitaban a los modelos fosilizados, sino que obviamente reflejaban las distinciones de género, sociales y laborales de cada comunidad y, por supuesto, la variación temporal de los gustos en el vestido. Lamentablemente quedan muy pocos testimonios físicos de esa indumentaria, ya que generalmente no se ha conservado por considerarse demasiado cotidiana y vulgar, y sobre todo por no poder apropiarse como característica o exclusiva de ninguna comunidad.

La indumentaria que se llevaba en Extremadura hace cien o ciento cincuenta años no se diferenciaba gran cosa de la que podríamos encontrar en la mayor parte del centro de la España peninsular. El análisis, todavía pendiente en este sentido, de la rica documentación notarial que recoge contratos matrimoniales, cartas de dote o inventarios de bienes post mortem revelaría seguramente un panorama no muy distinto del de otras regiones españolas respecto a la ropa que era usual en los hogares de la región; de hecho, los trabajos que se han referido a estas fuentes destacan esa homogeneidad con el resto del territorio español, así como la lógica evolución de los usos indumentarios entre los siglos XVI y XVIII, en contraste con el concepto de lo tradicional como referido a una sociedad inmovilista y anclada en el tiempo (Testón 1985: 101-103; Hernández Bermejo 1990: 176-177; Santillana 1992: 127-136; Zarandieta 2000: 84-87; Valadés 2011: 149-153).

A falta todavía de la explotación de estos repertorios documentales, la aproximación a la manera de vestir puede hacerse a través de las imágenes de las gentes extremeñas que nos dejaron los artistas y fotógrafos que desde el siglo XIX visitaron o habitaron la región; entre ellas, las primeras colecciones de estampas sobre tipos españoles - Cruz Cano y Olmedilla, Antonio Rodríguez, Gamborino, Téllez- no suelen recoger la referencia a los extremeños, aunque sí aparecen en la Colección de Trajes de España de Ribelles y Carrafa (1825), donde el labrador extremeño se representa llevando un sombrero chambergo de ala ancha y copa baja ( $\mathrm{n}^{\circ} 55$ C우 14웅 fig. 1), chaqueta de paño sin solapa con botonadura y con adornos de pasamanería en bolsillos y bocamangas, chaleco de doble botonadura, sin solapa y escote bajo y cuadrado sobre camisa amplia, sin cuello y bordada en el escote, faja, calzón de paño ajustado y abrochado con cintas por debajo de la rodilla y polainas de paño abotonadas; un tipo que se aproxima a la tipología de los trajes que se han conservado sobre todo en la provincia de Cáceres, aunque con elementos poco usuales como el ala del sombrero o algunos detalles de la chaqueta. La labradora extremeña ( $\mathrm{n}^{\mathrm{o}}$ 14, Co $4^{\circ}$ ) lleva una larga saya plisada con delantal claro, jubón y pañuelo claro, parecido a un dengue que no se ata por las puntas, y la cabeza descubierta. El choricero extremeño ( $\mathrm{n}^{\mathrm{o}}$ 14, $\mathrm{C}^{\mathrm{o}} 4^{\circ}$ ), figura común en la corte madrileña en esos años, lleva una indumentaria muy similar a la del labrador, aunque se cubre con un gabán corto y porta unas alforjas para su mercancía. 
De menor interés es el grabado de Langlumé trazado en 1829 a partir de los recuerdos de Clerjon de Champagny, un soldado francés que formó parte de la expedición de los Cien Mil Hijos de San Luis en 1823 y que describió la indumentaria masculina en Montehermoso a base de "trajes de cuero bastante elaborados" hechos con piel de gamo y gacela. En la ilustración que acompaña el texto se ve un hombre ataviado con un sombrero calañés de ala ancha, una chupa sin mangas sobre una camisa de manga larga, un calzón que llega hasta la rodilla protegido por lo que parecen unos zahones de cuero, medias de lana de color azul y un calzado similar a unas madreñas de madera. Del escaso rigor de la representación da idea el texto del militar francés, que describe Montehermoso como un inaccesible vergel, "un pueblo de la apacible Suiza transportado por un golpe de viento" al convulso suelo patrio, donde las viviendas son de «bloques de mármol en bruto, amontonados los unos sobre los otros" (Champagny 1829: 36).

Por su parte, el Semanario

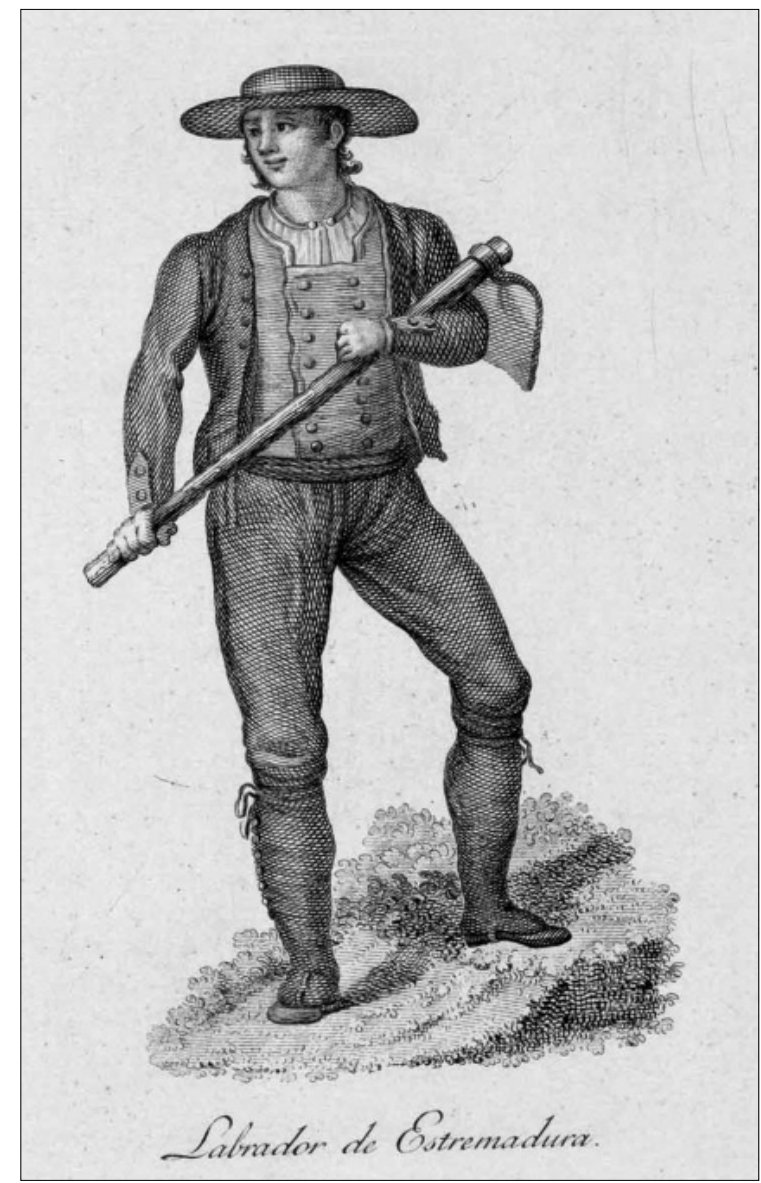

FIgURA 1.-Labrador de Extremadura. Colección de trajes de España. J. Carrafa, y J. Ribelles (1825).

Pintoresco Español del 24 de enero de 1847 publicaba un grabado ilustrando el artículo de Rafael Monje "Una boda en Carrascalejo". El dibujo no ofrece mucho detalle, y hemos de suponer que no es fidedigno, ya que probablemente su autor no presenció las escenas que describe el artículo, pero en él se representa a la moza con el cabello suelto y ataviada con un pañuelo de talle, similar al tipo de sandía, que probablemente cubre el jubón; el refajo es largo, amplio y plisado, con cortapisa y ribete en los bajos, y los zapatos parecen ser de lengüeta sobre medias de ganchillo. Por su parte, el mozo lleva sombrero de ala ancha y copa ligeramente troncocónica, más similar al cordobés que el de los grabados de Ribelles y Carrafa; la chaqueta es corta con cuello ajustado y unido a la solapa, aparentemente ribeteada en el borde, y con los bolsillos con tapeta y decoración en la bocamanga, sin que se aprecie la botonadura, el chaleco es de color claro, quizá de satén, con solapa y escote en pico bajo, y botonadura simple; el calzón es corto, hasta la rodilla, tal vez sujeto por una faja 
bordada que se adivina bajo el chaleco y las polainas quedan por debajo del calzón dejando ver parte de las medias de color blanco. Se trata, pues, de un modelo bastante diferente al grabado que vimos anteriormente, y que se aproxima pero no coincide exactamente con la descripción de los trajes que Monje da en el texto; según ésta, la moza se recogía el pelo en un moño con una cinta rizada que le colgaba hasta la cintura y el aderezo se componía de los pendientes de lazo y la cruz, con esmaltes en verde; llevaba jubón de franela negro con dos relicarios prendidos con lazos de cinta, y sobre él un pañuelo blanco; la basquiña era de falda recortada, es decir, que dejaba ver los pies que se alojaban en zapatos de dos costuras sobre medias de algodón blanco. El traje del mozo lleva sombrero calañés con cinta rizada, chaquetilla corta y chaleco de barbutería negro sobre camisa bordada, faja encarnada, calzón ajustado, calceta blanca y botín hasta la media pierna (Monje 1847: 36).

El tipo del extremeño aparece también en alguna aleluya fechada a mediados del siglo XIX como la conocida Habitantes de las provincias de España. Colección de Trages Españoles (n⿳0 28) de Hernando, impresa en el taller de J. M. Marés (Caro Baroja 1990: 506), donde aparece una pareja de extremeños en que apenas se distingue el sombrero calañés y la capa del hombre, y el moño de la mujer que asoma sobre el pañuelo de cabeza que viste sobre un mantoncillo. Las figuras están sobre la leyenda «El estremeño, jamones / trae en cambio de doblones ${ }^{3}$. Esa misma caracterización de jamonero la encontramos en el extremeño representado en una aleluya de Josep Rubió con los trajes típicos impresa en Barcelona, en que el hombre de nuestra región parece llevar un sombrero de tres picos y una capa terciada que deja ver una chaqueta corta sobre un chaleco de escote cuadrado ceñido con cintas, los consabidos calzones hasta la rodilla y medias 4 . De los mismos años deben ser las aleluyas madrileñas Lotería para los niños. Con los trajes de todas las provincias de España y número de habitantes que tiene cada capital y Rifa para los niños. Con los trajes de las mujeres de todas las provincias de España, en la primera de ellas se representa al hombre de Badajoz y al de Cáceres, el primero ataviado con un capote corto, chaleco de doble botonadura, calzón y polainas con una alforja al hombro, mientras que el segundo va embozado en una manta rayada y parece llevar un pantalón largo hasta el pie, con un sombrero parecido al de la estampa de Ribelles 5 . La dedicada a las mujeres muestra una fémina de Badajoz de amplio mandil negro con refajo de color claro con dos cintas en la parte inferior, jubón ajustado y sobre él un curioso dengue sin cruzar, portando en la mano un sombrero de ala ancha y copa baja adornado con dos cintas; por su parte, la cacereña lleva refajo largo oscuro con amplia faltriquera, jubón ajustado y sobre él un pañuelo de cabeza de color claro echado sobre los hombros y la cabeza descubierta ${ }^{6}$.

\footnotetext{
${ }^{3}$ Puede verse en http://jdiaz.cervantesvirtual.com/templates/paginas/obra.php?obra=habitantesde-las-provincias-de-espana\&tipo=aleluya (Consultado el 13 de agosto de 2013).

${ }^{4}$ http://jdiaz.cervantesvirtual.com/templates/paginas/obra.php?obra=trajes-tipicos\&tipo=catalogo (Consultado el 13 de agosto de 2013).

5 http://jdiaz.cervantesvirtual.com/templates/paginas/obra.php?obra=loteria-para-los-ninos-conlos-trajes-de-todas-las-provincias-de-espana-y-numero-de-habitantes-que-tiene-cada-capital$2 \&$ tipo=catalogo (Consultado el 13 de agosto de 2013).

${ }^{6}$ http://jdiaz.cervantesvirtual.com/templates/paginas/obra.php?obra=rifa-para-los-ninos-con-lostrajes-de-las-mujeres-de-todas-las-provincias-de-espana\&tipo=catalogo (Consultado el 13 de agosto de 2013).
} 
La obra anónima Recuerdos de un viage por España publicada entre 1849 y 1851 por la madrileña Imprenta de Mellado recoge también una imagen que representa una pareja de extremeños; aquí, la indumentaria del varón es prácticamente igual en todas sus prendas a la de la imagen de Ribelles y Carrafa, con el añadido de una capa larga. El vestido de la mujer se aprecia con dificultad, pero parece ser de una pieza con una falda larga y mangas afaroladas, cubriendo el talle con un pañuelo de color claro y llevando la cabeza descubierta.

Pero para esta época tenemos ya el testimonio de la fotografía. Uno de los ejemplos más antiguos de la fotografía en Extremadura es la famosa imagen del rollo de Jarandilla de la Vera, tomada por Charles Clifford en 1858 probablemente en su viaje para fotografiar las obras de restauración del puente de Alcántara (López Mondéjar 1989: 8); en ella, podemos ver varios personajes ataviados con ropas burguesas, acaso individuos que acompañaban al fotógrafo por tierras cacereñas, pero entre ellos se divisa un hombre, probablemente el alcalde del pueblo, vestido a la antigua usanza, con su sombrero calañés de los llamados de embudo con ala corta y vuelta adornado con borlas, su capa — como corresponde al día especial de recibir a los visitantes ilustres-, su chaqueta apenas visible y el chaleco de escote en pico, solapas y botonadura simple. Esta indumentaria no se diferencia mucho de la que llevan algunos personajes que están en segundo término, con calzones hasta la rodilla y polainas, y el mismo tipo de sombrero que alternan con los atuendos más modernos de los señores de la izquierda, con sus casacas de solapa ancha y pantalones largos hasta el pie. Es el momento en que las formas antiguas del vestido, emparentadas desde luego con el traje salmantino, están ya dando paso en los pueblos extremeños a las modas más urbanas y estandarizadas que se van imponiendo en toda Europa, tanto en su versión más humilde, como en la más ostentosa de los otros personajes de la fotografía. Algo similar se aprecia en la imagen que Clifford toma de los arrabales de Mérida que se viene fechando en 1859 (Muro 2000: 131), en la que conviven prendas antiguas y modernas reflejando una evidente estratificación social; aquí, las mujeres visten pañuelo de cabeza y pañuelo de talle, refajo largo y mandil, con una amplia variedad de diseños y colores que poco tiene que ver con la imagen estandarizada del traje regional.

De la misma época es una imagen que se fecha en 1861, comercializada por J. Laurent, que representa al Principal de los gitanos de Zafra (Muro 2000: 122), un castizo personaje que aparece con su sombrero calañés de pana, con ala vuelta, copa alta y cónica y adornado con borlas, pañuelo de cabeza bajo el sombrero, camisa de mangas amplias, chaleco que parece de seda, bordado con motivos florales, y terciada una preciosa chaqueta corta literalmente cuajada de una decoración floral que invade mangas y espalda; lleva también una ancha faja que le sujeta el calzón que le llega por debajo de la rodilla, abotonado a todo lo largo del muslo, y polainas de guarnicionería con botines. A partir de 1872 se publica la monumental obra Las mujeres españolas, portuguesas y americanas, que incluye sendos dibujos del artista de Fuente de Cantos (Badajoz) Nicolás Megía (1845-1917), reproduciendo el traje de las provincias de Badajoz y Cáceres. Los diseños, que no podemos considerar muy fidedignos, presentan escasas diferencias entre sí; el traje de Badajoz, que Megía debía conocer mejor, es representado con un pañuelo de talle que no corresponde con los modelos más conocidos, a no ser que se trate de un pañuelo de sandía mal colorea- 
do en la ilustración, mientras que el refajo amarillo se remata con tres cintas de terciopelo negro y amplia lorza por encima de ellas; el jubón es negro y de manga estrecha y el mandil negro, tal vez de raso, muy pequeño; el traje se completa con unas inusuales medias azules (Fig. 2). La cacereña se representa con jubón negro de mangas amplias sobre el que parece llevar una pañoleta blanca y sobre ésta, esclavina de color miel; el refajo rojo con su labor de picado negro en la parte inferior sí es reconocible en trajes que han pervivido en la provincia, algo menos las escasas dimensiones del mandil (Sánchez Franco 2008: 222). Pero también es interesante la descripción que hace Antonio Hurtado del traje de la cacereña en el texto que acompaña el grabado, que vemos que no guarda mucha relación con la imagen:

Para la artesana de Cáceres [...] mantilla de merino o de sarga de seda, redonda, que llega por detrás a la mitad de la espalda y por delante hasta poco más debajo de la cintura. Esta mantilla va festonada de una ancha franja de terciopelo, que adorna al exterior toda la circunferencia; y en el interior va revestida de un viso de tafetán de color de rosa, en lo general, que, cubriendo todo el casco y descendiendo por uno y otro lado hasta los hombros, viene a constituir lo que en lo antiguo se conocía con el nombre de rebociño. Esta prenda solo sirve para el templo, para calle y para paseo, pues para las romerías se sustituye con un pañuelo de seda de colores vivos, que, prendido a la cabeza por un alfiler, se deja flotar al viento con cierta coquetería. En los bailes no se usa ni la mantilla ni el pañuelo.

Ya, por lo general, el cuerpo y la falda del vestido son de una sola tela, aunque todavía se ven corpiños de pana o terciopelo negro, con botones de plata en las bocamangas. Se cubren el pecho, dejando siempre el escote bastante para lucir la garganta, con una pañoleta blanca de lino y con otro pañuelo grande de vivos colores, cuyas puntas se cruzan a la cintura y se dejan caer por detrás. Llevan media blanca, zapato escotado con lazos o con hebillas, arracadas y gargantillas de oro afiligranado de Portugal, y un moño anchísimo en forma de ocho, compuesto de una multitud de ramales trenzados, imitando la esterilla. Algunas llevan grandes rizos, cogidos a las sienes con horquillas de acero, y otras los recogen detrás de las orejas graciosamente. Para los duelos y los oficios de Semana Santa llevan corpiño y falda negra; pero nunca la falda es tan larga que no permita ver el pie.

[...] La mujer no artesana, o sea la que pertenece a la clase labradora, lleva casi el mismo traje, salvo que las prendas son más burdas, y que las faldas pecan de excesivamente cortas; tan cortas, que allí hay perpetua exposición de pantorrillas.

A dos leguas de la capital están enclavados varios pueblos que no dejan de tener su importancia relativa; pero siendo los trajes casi iguales a los de la clase baja de la capital, se distinguen por el color de las sayas, que unas son azules, otras amarillas y otras verdes.

En la orilla del Tajo, ya la cosa es más pintoresca y más significativa. Las mujeres en un día de gala llevan, en su mayor parte, jubón ajustado de terciopelo, pañoleta blanca bordada encima, falda corta de grana, media de vario color, zapatos con grandes hebillas de plata, y un guardapiés que, a veces suelto, a veces ceñido a la cintura y recogidas las faldas a la cabeza, las sirve de manto, a guisa de las limeñas o de las antiguas tapadas del tiempo de Felipe IV. En este punto la mantilla se usa poco; sólo se usa para los duelos y visitas de pésame, y su forma es como la de los mantos de las dueñas.

Inútil es decir que las gargantillas y las arracadas de filigrana son allí joyas indispensables. Portugal está cerca, y el arte de la orfebrería no da otra cosa de sí, excepción hecha de unos pendientes largos, que en forma de sartas de perlas desiguales y rematados por una bolita de oro vienen a alternar con las arracadas en figura de media luna, y de oro género de pendientes que a manera de cornucopias suelen estar tachonados de unas piedras que quieren ser esmeraldas (Hurtado 1872: 171-172). 
También de esos mismos años deben ser cuatro fotografías menos conocidas que parecen ser de la autoría del polaco Luis Tarszensky, autonominado Conde de Lipa, llegado a España en 1860 y que realizó cientos de vistas, algunas de temas extremeños, aún por estudiar en profundidad (López Mondéjar 1989: 34). Dos de las imágenes corresponden a hombres, y las otras dos son de mujeres ${ }^{7}$. Se trata de fotografías de estudio, mal conservadas, que deben datarse entre 1867, fecha en que se documenta la presencia de Lipa en Cáceres, y 1871, año de su fallecimiento. En ellas parece apreciarse que se ha retratado a dos parejas; en la primera, la mujer viste un traje de trabajo o diario con su pañuelo de cabeza echado sobre los hombros, pañuelo de busto y refajo largo de color liso con cortapisa en los bajos, y mandil de hilo fino o satén claro contorneado

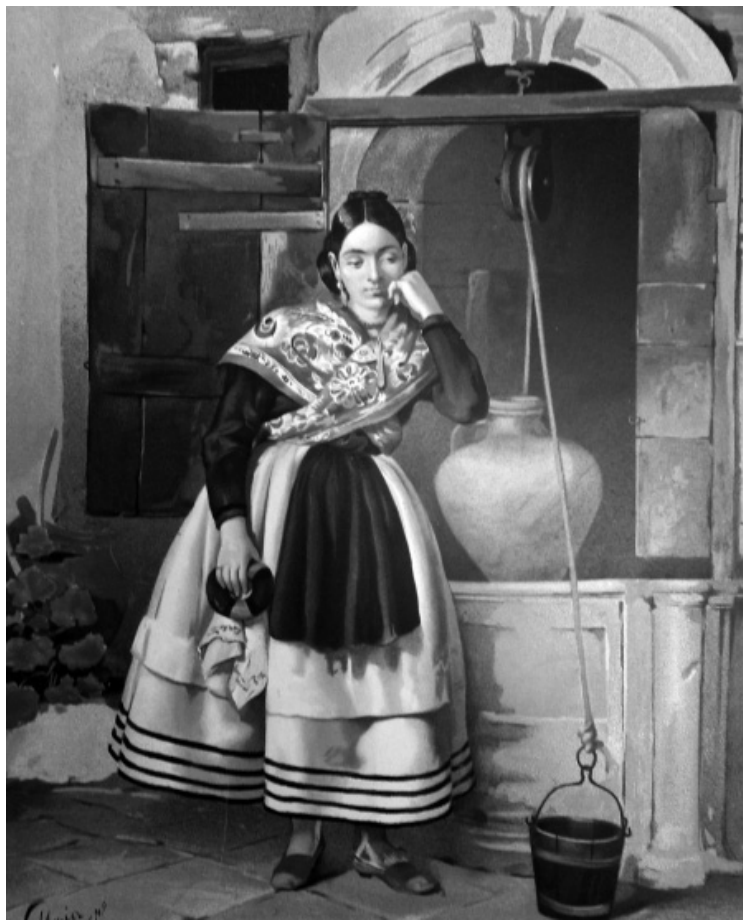

Figura 2.-Mujer de Badajoz. Las mujeres españolas, portuguesas y americanas. Nicolás Megía (1872). de puntilla. El modelo masculino, por su parte, lleva un atuendo similar al de los hombres de la foto de Clifford, con un sombrero parecido al del alcalde de Jarandilla, pero muestra un chaleco de paño oscuro cruzado por el frente, ribeteado de una cinta de color claro y presumiblemente sin botonadura, atándose con cintas, tal como se aprecia en el reproducido por Ruth Matilda Anderson procedente de Malpartida de Plasencia (1951: 88), y zahones sobre los pantalones. En la segunda pareja, el hombre lleva chaqueta, calzón y polainas de paño negro y sobre ellos una zamarra larga de cuero, en coincidencia con numerosas representaciones del mercado de los martes en la plaza de Plasencia, como luego veremos. En cuanto a la mujer, va con la cabeza descubierta, y se peina con moño de picaporte, lleva un dengue o esclavina ribeteado sobre jubón decorado en las bocamangas, y refajo corto (mantilla) y de amplio vuelo; sobre el refajo, un mandil de grandes dimensiones de color negro con una lista clara cerca del borde inferior, zapatos de lengüeta y las medias de color claro bien visibles por la cortedad del refajo. Si se completa el traje con el aderezo de joyas de filigrana y una cruz tembladera, vemos que estas cuatro imágenes son probablemente las más antiguas que se conocen de los trajes de Malpartida de Plasencia y Montehermoso, respectivamente.

\footnotetext{
${ }^{7}$ Las imágenes pueden consultarse en el Fondo Fotográfico de la Universidad de Navarra. http:/ /coleccionfff.unav.es/bvunav/i18n/consulta/busqueda_referencia.cmd?campo=idautor\&idValor=6735 (Consultado el 13 de agosto de 2013).
} 
De Montehermoso son los trajes que aparecen en las fotografías de J. Laurent realizadas con motivo de la boda real de Alfonso XII con su prima María de las Mercedes; como es sabido, para dar realce a las fiestas oficiales por el casamiento, concurrieron a la capital representantes de una veintena de provincias para exhibir los trajes típicos y bailes de los diferentes territorios de España (Gutiérrez 1993), y en el caso de Cáceres se eligieron seis parejas de vecinos de Montehermoso, cuyo traje ya había adquirido fama por su singularidad dentro de la provincia ${ }^{8}$, que fueron acompañados de un tamborilero y probablemente del alcalde de la localidad ${ }^{9}$. Para ello, la Comisión de la Diputación acordó en sesión de 7 de enero de 1878:

Enviar seis parejas de ambos sexos de vecinos de Montehermoso para contribuir con la exhivición $[s i c]$ de sus trajes característicos y típicos de gran parte de la provincia á las funciones y festejos que han de tener lugar en la Corte con tal motivo. Para acompañarlos, alojarlos y suministrarles lo necesario para su sostenimiento, se designa al empleado de la Diputación Don Santiago González, a quien se le satisfarán los gastos que se le originen en el desempeño de dicha Comisión (Valadés 1994: 107).

Así pues, las diferentes diputaciones provinciales, y Cáceres entre ellas, enviaron comparsas ataviadas con los trajes típicos de las provincias para exhibirlos y danzar para los reyes recién casados. Estaba prevista su actuación ante ellos el 25 de enero junto a las veinticuatro tiendas de campaña en que se mostraban en el Paseo del Prado, pero no fue posible por la masiva asistencia de más de 20.000 personas. Finalmente, bailaron frente a los Reyes en la Plaza de la Armería al mediodía del día 27, siendo obsequiados con un gran almuerzo y entradas para la corrida de toros de esa $\operatorname{tarde}^{10}$. Estas comparsas, y una pareja de cada una de ellas, fueron fotografiadas por J. Laurent ${ }^{11}$, que reunió así una buena colección de instantáneas de la indumentaria típica de las diferentes regiones españolas, las cuales comercializaría años después mediante álbumes y tarjetas postales que circularon hasta las primeras décadas del siglo XX y contribuyeron en gran manera a fijar el tipo del traje de cada provincia en el imaginario colectivo español. La pareja de montehermoseños fotografiada por Laurent quedó establecida como la imagen de la indumentaria de Extremadura y, coloreada sin criterio por diferentes artistas, sirvió para numerosas series de trajes españoles hasta la aparición de Sorolla y su serie para la Hispanic Society of America.

Es evidente que el traje que llevaron estos montehermoseños para presentarse en la Villa y Corte era un atuendo de gala, diferente del que en fechas no muy distintas se podía ver los martes de mercado en Plasencia. El 8 de noviembre de 1888 publi-

\footnotetext{
${ }^{8}$ Sin embargo, dos meses antes, la Diputación eligió los trajes populares de Malpartida de Cáceres y Serradilla como trajes significativos de la provincia para representarla en la Exposición Universal de París de 1878 (Acta de la sesión del Pleno de la Diputación Provincial del 6 de Noviembre de 1877).

${ }^{9}$ Aunque las actas del pleno del Ayuntamiento de Montehermoso no se refieren a esta expedición, llama la atención que reflejen la ausencia del alcalde, Lorenzo Garrido, en las sesiones del 19 y 26 de enero, probablemente por acompañar a la comparsa en Madrid (Libro de Actas de los plenos del Ayuntamiento de Montehermoso, Año 1878).

${ }^{10}$ Diario La Época, días 19, 26 y 28 de Enero de 1878.

${ }^{11}$ La fotografía del grupo puede verse en la página web de la Fototeca del Patrimonio Histórico Español, http://www.mcu.es/fototeca_patrimonio/ № de inventario VN-00990 (Consultado el 13 de agosto de 2013).
} 
caba La Ilustración Española y Americana un grabado sobre dibujos de Juan Com$\mathrm{ba}^{12}$ en que se apreciaban dos escenas de dicho mercado, en una de las cuales se representan dos hombres con la zamarra de cuero muy similar a la de la fotografía del Conde de Lipa, si bien van sin chaqueta y el sombrero se separa del tipo salmantino para asemejarse más al sombrero chambergo flexible que ha llegado hasta nuestros días como propio del traje montehermoseño. En la misma escena se puede ver a una mujer de espaldas, con su pañuelo en la cabeza, lo que parece un pañuelo de talle y la típica mantilla de Montehermoso en cuya cintura cuelgan las cintas de sígueme pollo. Pero aún más interesante es, en el mismo grabado, la representación esquemática de una mujer ataviada con una gorra de paja cuya única decoración parece estar en el frente de la copa, la cual lleva sobre el pañuelo, sin que le falten las prendas propias montehermoseñas, como la esclavina y la amplia mantilla. Este dibujo fue identificado por Ruth Matilda Anderson como la más antigua representación conocida de la gorra de Montehermoso (Valadés 1994: 103), una prenda de trabajo que debía estar comenzando a utilizarse, como se aprecia en el hecho de que el mismo grabado representa al menos a otras cuatro mujeres sin ese tocado. Vemos, pues, que en esos años finales del siglo XIX está fijándose el modelo del traje de Montehermoso, que por su vistosidad y peculiaridad es elegido para representar a la provincia en un evento importante como la boda real de 1878, pero vemos también que el uso de la gorra no está asociado al traje festivo, sino como prenda de trabajo.

En la misma revista, La Ilustración Española y Americana, se había publicado el 22 de diciembre de 1880 un grabado reproduciendo dibujo del natural de Joaquín Araújo, titulado El banco de la paciencia, que muestra la figura de dos hurdanos, en que uno corta el pelo al otro. Sus sombreros parecen ser de los tipos calañés y chambergo, los chalecos se asemejan al de Montehermoso, aunque llevan abotonada la solapa para mejor protección del frío, la camisa es de mangas amplias y los calzones llegan por debajo de la rodilla dejando ver los calzoncillos al no llevar polainas; uno de ellos lleva sobre el calzón unos protectores a modo de zahones, tal vez de piel de cabra, pero lo que más llama la atención es el calzado, reducido a lo que parecen unas groseras y desgastadas albarcas en un caso y zapatos de cordones muy usados en el otro.

De estos mismos años, disponemos de un interesantísimo documento en la fotografía del Sábado de Gloria en la Plaza de Trujillo, tomada en 1886 por el ingeniero Narciso Martínez Gutiérrez, en la que puede verse una gran cantidad de personas de ambos sexos y diferentes edades y estratos sociales que participan en la fiesta de ese día, en que los niños, ataviados como pastores, ofrecen en venta sus corderos para ser consumidos en el frite campestre del día siguiente. De entre los hombres, sólo una exigua minoría, alrededor de media docena, visten a la antigua, con su chaqueta corta, chaleco, sombrero de ala ancha y calzón corto; un par de ellos parece llevar zahones y sólo uno viste una amplia zamarra que parece de lana. Entre el resto de los atuendos masculinos abundan las chaquetas más largas y los pantalones hasta los pies, apareciendo numerosas corbatas, bombines y falsos bombines a los que se da

\footnotetext{
${ }^{12}$ La representación debe ser fidedigna como corresponde a la obra de un hombre que fue el primer director técnico de la Exposición del Traje Regional y profesor de "Historia del traje nacional" hasta su muerte en 1924 (Vega 2002: 30).
} 
forma con el canto de la mano, no faltando tampoco algunas capas, asociadas en todos los casos a vestimentas de tipo urbano. En cuanto a las mujeres, hay una gran variedad de vestidos, y aunque algunas jóvenes llevan el moño descubierto, la gran mayoría se cubre con un pañuelo de cabeza; lo generalizado es el uso de un pañuelo de talle o mantón y refajo largo con amplio mandil, pero hay una enorme variedad de colores que poco o nada tiene que ver con la idea del traje regional, y no deja de llamar la atención que no se distingan los refajos con labor de picado o que sólo en contados casos infantiles, y con dudas, se identifique la pollera tejida en lana de colores, prendas ambas que se suponen propias del traje trujillano (García y otros 1998: 65).

En 1887 se publica la obra Extremadura, de Nicolás Díaz y Pérez, que incluye dos ilustraciones de Saumell litografiadas por Pigrau reproduciendo los mismos trajes de la célebre fotografía de Laurent, pero coloreados arbitrariamente y atribuyendo a Badajoz el traje de montehermoseño, tal como señaló Anderson (1951: 322).

No muy lejana en el tiempo, de hacia 1890, es una fotografía tomada por un aficionado vasco, Eugenio Garay Rivacoba, que era terrateniente en Membrío (Cáceres), representando una familia de piconeros en que aparecen cuatro generaciones de trabajadores del campo (Muro 2000: 38). Las cuatro mujeres y la niña visten pañuelo de talle, que sólo tiene colores claros en las más jóvenes, y las dos de más edad llevan pañuelo de cabeza, aunque la más anciana seguramente se lo quitó para posar y lo sostiene en su regazo, los refajos son largos y plisados apreciándose el mandil sólo en una de ellas. Los dos hombres llevan sombrero de ala ancha, semejante al cordobés, pero de copa redondeada, el más mayor con una zamarra tal vez de cuero sobre lo que parece una chambra, y el más joven chaquetilla corta abotonada, faja y zahones. De entre las fotografías que a finales del siglo XIX empiezan a ser numerosas, solamente nos referiremos a una más, obra de Gustavo Hurtado Muro ${ }^{13}$, que se fecha en 1899 y representa a varias mujeres de diferentes edades cruzando el puente Concejo en la ciudad de Cáceres cargadas con canastas, cántaros y cestas (Muro 2000: 146). Todas ellas llevan refajos largos, distinguiéndose algún mandil tan largo como la saya, de color negro en las de más edad. Las jóvenes llevan refajos con o sin mandil, algunos de ellos estampados a cuadros, y pañuelos de talle de colores claros; el pañuelo de cabeza es común, aunque alguna de las retratadas no lo lleva, para sujetar mejor el cántaro sobre la rodilla tejida, y una de ellas, la más mayor, se cubre la cabeza con el mismo pañuelo de talle, a modo de cobija.

Por esos años circulaban por España distintas series de estampas con trajes de las provincias españolas. En la que la catalana fábrica de Chocolates Jaime Boix regalaba a sus clientes, el dibujo que representa el traje de Badajoz parece inspirarse lejanamente en el grabado de Nicolás Megía publicado en 1872, pero no tiene nada

\footnotetext{
13 Polifacético artista cacereño (1878-1960), hijo del que fuera Presidente de la Comisión Provincial de Monumentos, Publio Hurtado. Comenzó la carrera de Arquitectura para pasar a estudiar en la Escuela de Bellas Artes de San Fernando de la mano de profesores como Moreno Carbonero o Muñoz Degrain, formándose también como fotógrafo con Garrorena. Junto a Julián Perate fundó la Sociedad Artístico-Fotográfica de Cáceres y fue Catedrático de Dibujo de la Escuela Normal cacereña, académico correspondiente de la de Bellas Artes de San Fernando, miembro de la Junta de Patronato del Museo de Cáceres y de la Junta del Ateneo local, vocal de la Comisión Provincial de Monumentos, etc.
} 
que ver con lo que cuarenta años después se institucionalizó como el traje de la provincia, mientras que la estampa dedicada al de Cáceres reproduce, sin mucha exactitud, el traje de Montehermoso. La estampa de la fábrica castellonense de fajas Joaquín Ferreres representa al hombre de Montehermoso también tomado de la fotografía de Laurent; en estas representaciones fechadas alrededor de 1895, la montehermoseña aún aparece sin la gorra de paja y los colores de su traje no coinciden con los usuales, consecuencia de haber utilizado como modelo la fotografía en blanco y negro de Laurent.

Todos estos ejemplos antiguos nos están mostrando que a finales del siglo XIX estaba cambiando muy rápidamente el modo de vestir en los pueblos y ciudades de Extremadura, desapareciendo progresivamente las prendas que habían formado parte de la indumentaria habitual durante cien años, pero sobre todo muestran la variedad de diseños y colores que se utilizaban en esa ropa tradicional. Por un lado, vemos que la tipología variaba poco entre las distintas poblaciones e incluso con respecto a otras zonas rurales de España, siendo difícil distinguir la forma de vestir específica de una localidad, salvo casos muy concretos como Montehermoso, y por el otro se aprecia en esa variedad de diseño una amplia gama de posibilidades en cuanto a tejidos, colores y hechuras que tiene más que ver con las edades, circunstancias familiares y posibilidades económicas de quienes visten esas ropas que con un supuesto modelo de traje tradicional que todo el mundo llevaba.

\section{INDUMENTARIA Y PLÁSTICA REGIONALISTA}

A principios del siglo XX la fotografía comienza a popularizarse en la región y proliferan los ejemplos que ahora nos son útiles para analizar los usos en el vestir, pero en ese período también se acentúa el proceso de adopción de las nuevas modas, y las formas antiguas van quedando relegadas a las personas de más edad o a las áreas rurales más aisladas. Es el momento de la búsqueda de la pureza y la originalidad a que nos referíamos antes, en medio de la crisis nacional de comienzos de siglo y las ideas regeneracionistas. En ese contexto, Joaquín Sorolla recibe el encargo de la Hispanic Society of America para realizar su serie de pinturas sobre las tierras de España destinada a decorar la biblioteca de la institución neoyorquina; trabaja entre 1911 y 1919 en una empresa que ha sido considerada como el fundamento de la institucionalización del traje regional en España (Vega 2005: 74). Cuando, en 1917, le llega el turno a nuestra región, parece que el artista valenciano no tiene ninguna duda en elegir los trajes de Montehermoso; ya hemos visto que en fecha tan temprana como 1878 se consideró natural que fuese esta localidad la que representara a la provincia en las bodas reales, pero en esta ocasión, y por esa circunstancia, el de Montehermoso se va a convertir en el traje regional de Extremadura, o al menos en el modelo indumental capaz de simbolizar la identidad extremeña. A ese hecho contribuye el que en la provincia de Badajoz, mejor comunicada y con una mayor penetración de las modas urbanas en el ámbito rural, parece haberse perdido más rápidamente el gusto por los vestidos de los antepasados. Así, llama la atención que la Diputación badajocense no enviara delegación alguna a la boda de Alfonso XII, y aún más el que en 1908, con motivo del Centenario de la Guerra de la Independencia, el Ayun- 
tamiento de Badajoz declinara la invitación del consistorio madrileño para concurrir con su traje típico alegando que:

En esta población no hay persona alguna que vista el traje típico de los antiguos extremeños ni se conservan datos que pudieran servir para reconstituir con exactitud dicho traje. (Vega 2005: 75).

Para la representación de Extremadura, Sorolla no creó como en el caso de Castilla una composición con trajes de las diferentes provincias, sino que se centró en el traje de Montehermoso, el cual sin duda conocía a través de las fotografías de J. Laurent que utilizó para documentarse (Vega 2002: 28), eligiendo la versión que podía verse en el mercado de Plasencia, donde pasó unas semanas pintando a sus modelos montehermoseños ${ }^{14}$. Así, su obra Extremadura. El mercado representa a cuatro hombres y otras tantas mujeres, más una niña; los hombres se visten tal como lo hacían para acudir semanalmente al mercado placentino con sus productos, como ya vimos en el grabado de 1888, pero las mujeres no posaron para Sorolla con su traje de diario, sino con sus mejores galas (Anderson 1951: 157), aunque el artista no pudo resistir la tentación de hacerlas cubrirse con la gorra de paja de centeno que tan conocida era entre los placentinos por verla habitualmente en el mercado de los martes. No hay que olvidar que para llegar a Plasencia desde Montehermoso era necesario un trayecto de cinco horas a lo largo de más de $25 \mathrm{Km}$. a lomos de mulas y cruzando en barca el río Alagón, por lo que las mujeres preferían cubrirse con esta gorra para protegerse del sol, tal como hacían para trabajar en el campo; pero en ningún caso la gorra se llevaba con un traje de fiesta, como en 1928 confirmaron sus informantes a Ruth Matilda Anderson, y como puede apreciarse perfectamente en una conocida fotografía suya de la Fiesta de las Candelas de ese año en la plaza de Montehermoso, donde no se ve ni una sola gorra y sí una buena variedad de vestidos femeninos que se apartan del traje canónico del pueblo (Anderson 1951: 119 y 161). El hecho es que a finales de 1917 Sorolla representó, seguramente por vez primera, el traje femenino de gala de Montehermoso con el aditamento extraño de la gorra, que siempre fue una prenda de trabajo y que además tenía una antigüedad que podría no remontarse a más de cuatro o cinco décadas. Acababa de inventarse una tradición, que apoyada en la singularidad de su decoración incluyendo un espejo, y con el aditamento de atribuir un uso diferenciado de los distintos modelos de gorra dependiendo del estado civil de la mujer que la llevaba, tenía asegurado el éxito para convertir el traje femenino de Montehermoso en un símbolo de la identidad extremeña y en imagen única de la indumentaria regional (Valadés 1994: 101-116).

\footnotetext{
${ }^{14}$ Entre el 20 de octubre y el 4 de noviembre de 1917, Sorolla estuvo en Plasencia alojado en casa de Fernando Sánchez-Ocaña Silva, alcalde de la ciudad, donde pintó su obra contratando como modelos a los cuatro hombres, cuatro mujeres y la niña que aparecen en el cuadro. Ruth Matilda Anderson conoció en 1928 a varios de ellos en Montehermoso y la propia casa en Plasencia, que entonces pertenecía al hijo, Pedro Sánchez-Ocaña Delgado. Sorolla pidió a sus modelos que llevaran buenos trajes, posando todos los días de diez a doce de la mañana por diez pesetas la jornada, además de los gastos de alojamiento en Plasencia; a su cliente Archer Huntington le dijo que había gastado 80 duros en pagar a los modelos. Las modelos eran Marcelina Domínguez Garrido La Carrasca, Rafaela Garrido, Matilde Galindo e Isabel Galindo; de los hombres identificó a Genaro Iglesias, de una conocida familia de fabricantes de cencerros, Jacinto Galindo y Rafael Galindo, y la niña era Frutosa Sánchez Garrido (Anderson 1951: 111 y 157).
} 
Por otra parte, para esos años se había iniciado ya en Extremadura un cierto movimiento artístico que buscaba en el costumbrismo y el casticismo el color local y la vuelta a las raíces que habían de contribuir a la regeneración del país. Al igual que Sorolla en Valencia, Zuloaga en Castilla, los hermanos Zubiaurre en el País Vasco o Romero de Torres en Andalucía, varios pintores extremeños del primer cuarto de siglo cultivan un arte regionalista ciertamente superado y voluntariamente alejado de la renovación de la plástica europea en esas décadas, pero de gran acogida entre el público y determinados sectores de la crítica. Entre ellos destaca Eugenio Hermoso (1883-1963), que durante casi toda la primera década del siglo XX trabaja el costumbrismo logrando grandes composiciones en que los vestidos y los rostros de sus modelos protagonizan su particular canto a la tierra. Su obra La Juma, La Rifa y sus amigas (1906) muestra a ocho niñas de Fregenal de la Sierra volviendo de la fuente con sus cántaros en la cintura. Ninguna de ellas lleva tocado ni pañuelo en la cabeza, visten refajos de distintos colores con mandiles blancos, grises o listados y blusas también de colores, siendo de destacar los pañuelos de talle entre los que se identifican dos de sandía y otros de flores. En el pequeño cuadro En la Fontanilla (1910) destaca el refajo amarillo liso, el jubón encarnado y un vistoso pañuelo de flores naturales con fondo negro. No menos valiosa es la obra A la fiesta del pueblo (1916), que obtuvo la Primera Medalla en la Exposición Nacional de Bellas Artes del año siguiente; en este cuadro, que puede contemplarse en el Museo de Cáceres, siete muchachas se dirigen a celebrar una fiesta campestre, portando cestos de frutas y un gallo para la comida. La variada y colorida representación de refajos y mandiles se complementa con el pañuelo de sandía y con un espectacular mantón de ocho puntas de merino, que se utilizaba igual como mantón de talle que de capa o encobijada; además vemos que tres de las muchachas llevan pañuelos de cabeza, dos blancos y el otro estampado.

La misma indumentaria de corte antiguo, equiparable a la que veíamos en testimonios fotográficos del siglo XIX, se puede ver en Romería de los Remedios (1919), donde además del pañuelo de sandía, vemos uno de cien colores, uno de seda adamascada, otro de flores naturales y uno de tres cenefas. Uno de los personajes masculinos lleva chaleco y camisa de amplias mangas, otro una chaqueta corta y sombrero de estilo prácticamente cordobés, y el guitarrista parece vestir una característica chambra mielera. Algo similar vemos en la obra ya tardía Una boda en Fregenal (1934), donde abunda el mismo tipo de sombrero con copa ligeramente troncocónica, frecuente en la indumentaria de la provincia de Badajoz, junto a chaquetas cortas de aire andaluz, pero, salvo detalles como el mantón de Manila que se divisa en la esquina inferior izquierda, en general se ve que los modos de vestir son muy distintos a los más antiguos y rurales de veinte años antes. El proceso se confirma en el cuadro El columpio (1944), donde las ropas que llevan los personajes ya no tienen nada que ver con los trajes populares del siglo anterior (VV. AA. 1999).

Menos conocida, pero también interesante, es la obra de José Pérez Jiménez (18871967), que en los años anteriores a la guerra civil pinta cuadros como Los recién casados o El ramito de flores, en los que se aprecia la convivencia entre modelos indumentales tradicionales, con presencia de zahones, blusas, chalecos y fajas rojas, junto a otros más modernos, especialmente en el atuendo femenino, que reflejan perfectamente el fin de una época (García y otros 1998: 8-9). Adelardo Covarsí (1885- 
1951) retrata, por su parte, el mundo de la montería y la caza, pero lo hace sin la exquisita atención a los detalles del ropaje que veíamos en Hermoso; destacan algunas de sus obras como El montero de Alpotreque (1948), cuya figura central es el padre del artista que viste un grueso capote, mientras los personajes secundarios llevan prendas de tipología muy variada, entre las que señalamos las zamarras de piel o los zahones de cuero. Más interesante es el cuadro Vareadores de Alburquerque, de fecha desconocida, que por su pequeño tamaño no permite mucho detalle en la representación, aunque se pueden ver la zamarra y los zahones del personaje más joven junto a los sombreros chambergos de los más mayores, la chaqueta de corte antiguo y la capa de color pardo (VV. AA. 2001).

En la estela marcada por Sorolla, hemos de citar la obra de Juan Caldera (18971946), en la que destaca Un mercado en Plasencia (1926), representación de una escena similar a la que vimos en 1888 y con rasgos comunes con la obra de Sorolla para la Hispanic Society; sin embargo, en Caldera encontramos un mayor rigor, pues representa a las mujeres con su gorra, pero en traje de diario, al igual que los hombres, uno de los cuales viste zamarra, y se tocan ya con el sombrero chambergo que ha permanecido en el traje montehermoseño. Anterior a esta obra es La huevera (1920), fechada en Malpartida de Cáceres, donde la niña lleva un pañuelo de manta de Arroyo de la Luz, refajo rojo y mandil negro, además del pañuelo de cabeza anudado, mientras la mujer mayor parece cubrirse con un mantón color pardo sobre el pañuelo de cabeza de luto, al igual que La moza del ajuar (1921), en que la modelo se cubre la cabeza con una mantilla de terciopelo negro y ribeteada en raso rojo, lleva una gargantilla de venera, jubón negro y pañuelo de talle de cien colores, refajo amarillo con una lorza y cinta de terciopelo negro y mandil largo negro con puntilla; las medias son blancas con cenefa de cadeneta y los zapatos son abotinados; es una versión prácticamente canónica del traje de campuza de la ciudad de Cáceres. Sin embargo, en Idilio pastoril (1922) nos encontramos con prendas extendidas por otros puntos de la región, como hemos visto: el pañuelo de sandía, los zahones y el sombrero chambergo (Guerrero 1980). Muy posteriores, e inferiores en calidad, son otras obras de Caldera, como Esperando al galán (1946), que representa una moza -la hija del pintor, en este caso- con el traje de fiesta de montehermoseña, pero ya con la gorra incorporada, que se va a imponer tras la obra de Sorolla y especialmente tras la publicación en 1933 de la serie de fotografías de Montehermoso de José Ortiz Echagüe a que nos referiremos más adelante; de hecho, la composición del cuadro de Caldera repite casi literalmente una de las más conocidas fotografías de esa serie.

Aunque podríamos citar algunos otros autores ${ }^{15}$, nuestra referencia a la pintura regionalista se cierra con Eulogio Blasco (1890-1960); pintor, escultor, cartelista y un verdadero maestro del repujado. Su obra se conoce menos que la de los anteriores, pero podemos citar varios de sus cuadros con representación de indumentaria tradicional (Bazán 1991: 37-45). Así, en Mujeres cosiendo (1928) dos jóvenes llevan el

\footnotetext{
${ }^{15}$ No nos proponemos presentar exhaustivamente el papel de la indumentaria en la pintura regionalista, lo que excedería el objetivo de este trabajo, pero entre los artistas con obra interesante en este sentido se pueden citar Felipe Checa, Conrado Sánchez Varona, José Morales, Víctor José Amador, Antonio Trajano, Manuel Antolín Romero de Tejada, Antonio Solís Ávila o Leopoldo Grajera, además del ya nombrado Nicolás Megía.
} 
pañuelo de sandía y sus pendientes de aro, gargantillas de bola y cruces de filigrana al pecho, los mandiles, a listas azules y cuadros en blanco y negro, y los refajos de colores oscuros. En Mujeres con cántaros vemos los pañuelos de sandía, omnipresentes en la obra de Blasco, junto a uno de tres cenefas y faltriqueras bordadas bajo los mandiles. Finalmente Montehermoseña, reproduce el modelo de Sorolla y de Ortiz Echagüe en lo que ya parece más una postal de publicidad turística que un estudio del traje popular.

\section{INDUMENTARIA E IDENTIDAD EXTREMEÑA}

Como hemos podido comprobar, en ese primer tercio del siglo XX se produce la práctica desaparición de las formas de vestir más antiguas que aún podían verse en Extremadura, y que habían quedado plasmadas en el registro fotográfico desde los años sesenta del siglo XIX, aunque haya sido posible, hasta no hace muchas décadas, ver todavía en algunos pueblos restos de aquella indumentaria en determinadas prendas o colores. Al mismo tiempo, queda fijado el modelo de traje regional encarnado en el de Montehermoso (Fig. 3), fundamentalmente por la aportación de artistas como Sorolla u Ortiz Echagüe, pero también por otros factores fundamentales, como la celebración de la magna Exposición del Traje Regional en Madrid (1925), en la que figuró ya un traje de montehermoseña con gorra ${ }^{16}$, de manera que el modelo recién creado contó a partir de entonces no

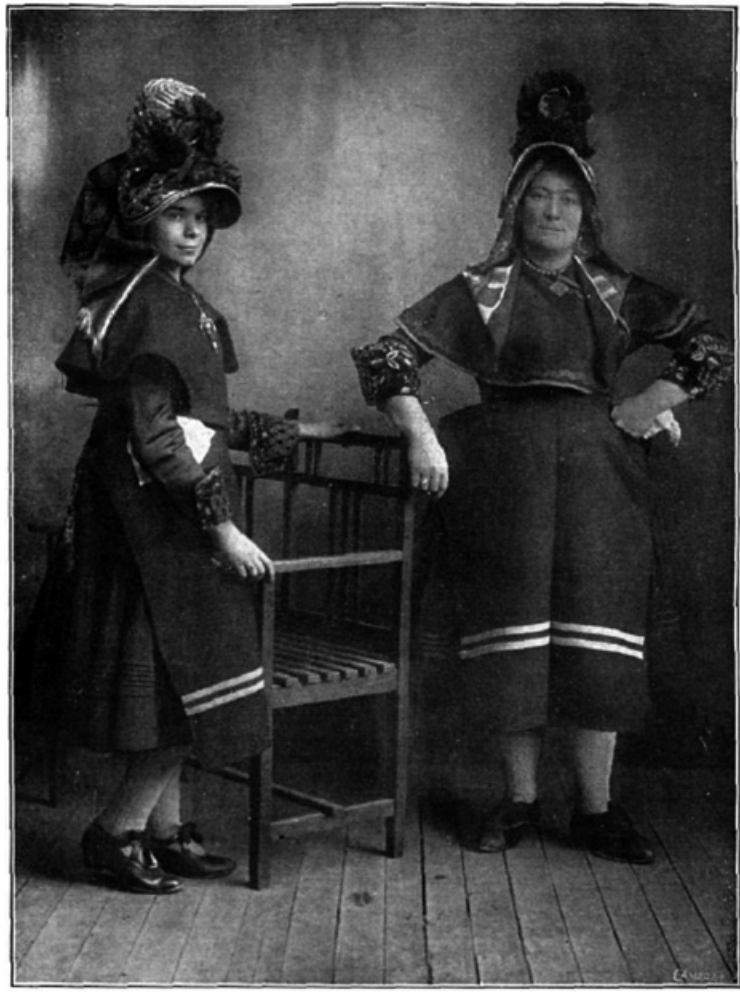

FIGURA 3.-Montehermoseñas con traje de gala y gorra de soltera. Fotografía de Cámara publicada en La Esfera, 22 de mayo de 1920.

\footnotetext{
${ }^{16}$ Los maniquíes que aparecen con el traje de Montehermoso en la fotografía número 178 del libro de Isabel de Palencia (1926) son con toda seguridad los de la citada exposición, que se había celebrado el año anterior. Palencia utiliza profusamente numerosas fotografías de la exposición en su libro. La imagen a que nos referimos muestra el traje festivo de la montehermoseña al que ya se ha incorporado la gorra, y el pie de la foto dice, significativamente: "Trajes de gala en Extremadura".
} 
sólo con el refrendo artístico, sino también con el espaldarazo científico de Luis de Hoyos, que entonces era la máxima autoridad en el estudio del traje español (Valadés 1994: 109). Por aquella época, los únicos trajes que seguían vigentes en Extremadura, y aún podían verse por las calles, eran los de Montehermoso, Malpartida de Plasencia y Torrejoncillo; treinta años más tarde podían considerarse ya perdidos, sólo se conservaba incompleto en Montehermoso, y en algunas aldeas del norte de la región "algún viejo todavía usa calzones" (Hoyos 1955: 353).

Es necesario aquí valorar el trabajo de Ruth Matilda Anderson, que recorrió Extremadura entre enero y abril de 1928 y, en una segunda oportunidad, entre 1948 y 1949. Conoció la obra de Hermoso y Covarsí, llegando a tratarles personalmente, como también a las personas que habían servido de modelo a Sorolla en 1917. Centró su interés en la indumentaria, pero también realizó un minucioso registro de muchas actividades económicas como el prensado de aceituna, la fabricación de tinajas, el corte y preparación del corcho, la calderería y fabricación de cencerros, la cura de jamones, el trenzado del esparto, la cría y venta de ganado, etc. En sus apreciaciones sobre la forma de vestir, advirtió la gran diferencia observada entre los dos viajes que realizó, ya que en esos años se había perdido el interés por las prendas tradicionales, las hijas habían dejado de vestir como sus madres y preferían los vestidos "finos y elegantes" a las "sayas de lana gruesa y los pañuelos", de modo que los trajes antiguos habían sido relegados a las arcas, "ahora el traje regional se reserva para las grandes ocasiones" (Lenaghan 2004: 35). Su obra es, sin duda, la más completa y rigurosa sobre la indumentaria extremeña, habiendo contado con el privilegio de comenzar la tarea de documentación en los años anteriores a la guerra civil.

Al referirse a Badajoz, Anderson observa todavía el uso ocasional de trajes tradicionales en Alburquerque, Campanario, Herrera del Duque o Navalvillar de Pela, pero aclara que la Sección Femenina de Badajoz, dirigida por una sobrina de Adelardo Covarsí, se encontró con que la ciudad había perdido su traje local distintivo, si es que alguna vez lo tuvo, por lo que se buscaron los modelos en La Serena, la comarca más rica en folklore de la provincia, y más concretamente en Campanario (Anderson 1951: 248 y 284). En el caso de Olivenza, describe cómo la Sección Femenina diseñó el traje local a partir de las descripciones de las mujeres mayores e inspirándose en modelos portugueses, y constata la pérdida total del traje en lugares como Almendralejo, Villanueva de la Serena o Don Benito, donde sin embargo parece que la propia Sección Femenina había instalado un telar que comenzó a producir los característicos refajos de listas blancas y negras horizontales que incorporó el llamado "traje de Badajoz" (Anderson 1951: 287); un tipo que Nieves de Hoyos ha observado que en realidad es de introducción reciente importada de Levante a través de La Mancha (Hoyos 1955).

Mucho más rica es la información que Anderson transmite sobre la provincia de Cáceres, donde, significativamente dedica un documentado y completo capítulo a los trajes de Montehermoso, estudiando también los de Guadalupe, Alía, Arroyo de la Luz, Valencia de Alcántara, Jarandilla, Aldeanueva de la Vera, Garganta la Olla y Cabezabellosa, Malpartida de Plasencia y Torrejoncillo, sin olvidar una incursión en Las Hurdes, donde señala la influencia salmantina en las personas que podían permitirse un traje de gala, siguiendo de cerca el relato que años antes había publicado Maurice Legendre. 
En efecto, unos pocos años antes que Anderson, entre 1910 y 1925, con el paréntesis de la Primera Guerra Mundial, había hecho su trabajo de campo en la misma comarca de Las Hurdes el geógrafo francés, que si bien no tenía el estudio de la indumentaria entre sus objetivos principales, sí hace mención de la ropa que hombres y mujeres llevaban. Resume la situación señalando que en los días de fiesta mayor la gente viste de manera parecida a como suelen hacerlo los campesinos pobres de las provincias aledañas, los hombres ricos con sombrero de fieltro grosero adquirido en Plasencia, chaqueta corta, chaleco azul de anchas solapas al estilo charro, camisa amplia de estopa, calzón de paño oscuro con polainas de paño negro y zapatos de cuero; la capa sólo la llevan los concejales, el resto lleva anguarina. Las mujeres visten pañuelo de lana en la cabeza (serenero), mantón de paño oscuro ribeteado de azul, esclavina de lana, camisa de es-

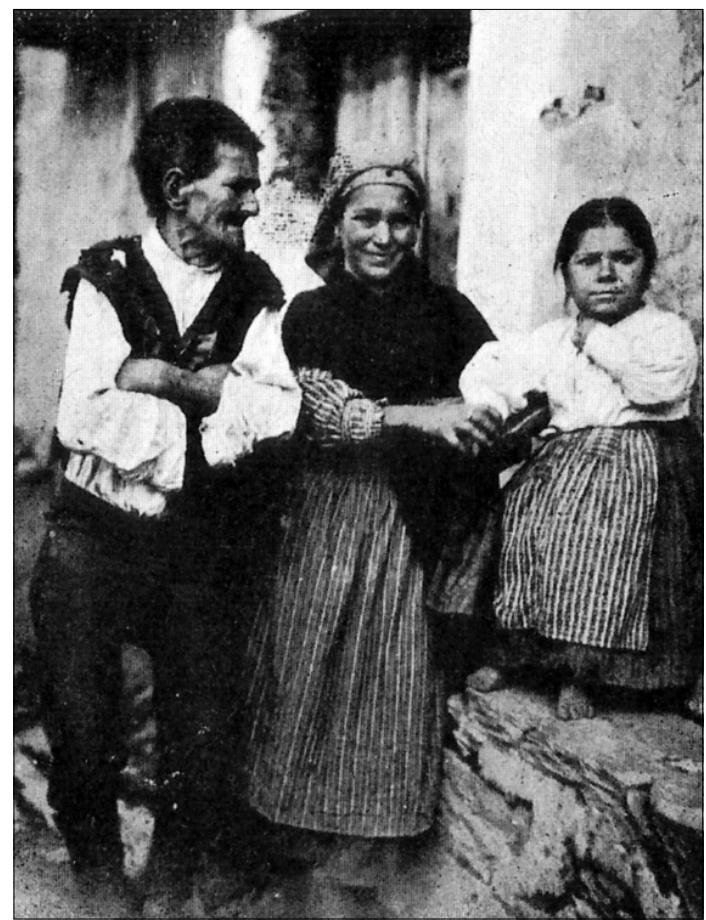

Figura 4.-Tres generaciones de una misma familia en Carabusino (Las Hurdes). Maurice Legendre. Las Jurdes. Étude de Géographie Humaine (1910-1925). topa o tela basta al estilo de Ciudad Rodrigo, bordada en lana negra en cuello, pechera y puños y zapatos de seda basta llamados de oreja de ratón, o bien con hebilla y tacón alto; pero evidentemente esto retrata el hecho extraordinario de un día de fiesta entre la población más afortunada. La realidad es, señala Legendre, que no existe un traje regional de Las Hurdes (Fig. 4), los hombres llevan calzones de paño grosero con polainas de paño, camisa larga de cáñamo o estopa y un peto de piel de cabra a modo de zamarra, zahones del mismo material y un sombrero viejo, ya que suelen comprar la ropa de segunda mano (mendos) en las poblaciones cercanas, y las mujeres la misma camisa que los hombres, pañuelo de talle de paño grosero con ribete azul y esclavina de lana fina o pañuelo de algodón azul; los zapatos eran un producto de lujo que pocos podían permitirse, y sólo usaban alpargatas en caso de extrema necesidad (Legendre 1927: 188-196). De la misma época es el célebre viaje que hizo el rey Alfonso XIII a Las Hurdes en 1922, cuyas fotografías tomadas por Campúa muestran un desolador panorama muy similar al descrito por Legendre (VV. AA. 1993).

En la misma línea que ya había abierto la Exposición del Traje de 1925, cuatro años después se presentaban en el Pabellón de Extremadura de la Exposición Iberoamericana de Sevilla algunos trajes populares de Alburquerque, Herrera del Duque, Villanueva de la Serena, Orellana la Vieja, Montehermoso, Malpartida de Plasencia, Casar de Cáceres, Torrejoncillo y Malpartida de Cáceres, que habían sido adquiridos en los diferentes pue- 
blos por Adelardo Covarsí, en la provincia de Badajoz y Miguel Ángel Orti Belmonte en la de Cáceres. En todos estos casos, los modelos elegidos quedarán fijados como auténticos para el futuro rescate y divulgación de los mismos por la Sección Femenina y por grupos folklóricos locales. En el caso montehermoseño, el traje de mujer elegido es el de fiesta incorporando la gorra de trabajo, tal como pasó al Museo de Cáceres ${ }^{17}$ tras la clausura de la exposición, permaneciendo expuesto entre 1933 y 1972.

Cabe subrayar la aportación del fotógrafo José Ortiz Echagüe a la difusión de la montehermoseña ataviada con su traje de gala y tocada por la gorra; no debe olvidarse que Ortiz Echagüe es un artista que prima la construcción personal de la obra sobre la documentación objetiva, no dudando en sacar de contexto la realidad en pro de la creación artística. Su hermano, el pintor Antonio Ortiz Echagüe era seguidor de Sorolla y en 1916 el propio José llegó a entablar amistad con el valenciano al coincidir en París, precisamente cuando Sorolla trabajaba en su serie neoyorquina; no puede negarse la influencia del gran pintor en la manera de preparar las escenas con los trajes más vistosos sin reparar en su autenticidad. En 1925, Echagüe ya estaba recorriendo España retratando tipos y trajes populares; en su afán por que los modelos vistiesen las incómodas y anticuadas ropas de sus antepasados, encontraba no pocas dificultades, como cuenta su hija:

Papá sabía la historia de todos los lugares, hablábamos con sus gentes y convivíamos con ellos durante días; convencíamos a los pastores para que pusieran el rebaño a nuestro gusto; "Sobornábamos" a las mozas para que vistieran las galas de fiesta... Y revolucionábamos el tranquilo pueblo (Vega 2002: 53).

La enorme difusión alcanzada por las fotografías de Ortiz Echagüe en las numerosas ediciones de sus libros y las frecuentes exposiciones realizadas en el extranjero y en España le sitúan como uno de los principales responsables de la asimilación de la imagen del traje montehermoseño con la gorra y su conversión en traje regional (Vega 2002: 42-54). Estas fotografías consagran la imagen de la montehermoseña con su traje de gala y la gorra como aditamento, en sustitución del pañuelo que realmente llevaba. Sólo las aguadoras aparecen sin gorra, y por la razón obvia de la imposibilidad de cargar con el cántaro sobre la cabeza. El propio Echagüe señala su incorrección al describir la indumentaria de las mujeres el día del Corpus Christi:

Hoy llevan pañuelos de seda sobre sus cabezas, a diario llevan extraños y grandes sombreros de amplia copa abombada puestos sobre los pañuelos, los que cruzan por delante de la boca.

Las mujerucas ancianas llevan trajes de la misma hechura, todos en negro, sombreros bordados en obscuro, pañuelos también negros que cruzan por delante ocultando medio rostro (Ortiz Echagüe 1933: 8).

A partir de estos años, y particularmente desde el final de la guerra civil con la labor de la Sección Femenina, se acentúa y consolida el proceso de simplificación, estandarización y actualización de los tipos destinados a representar el traje regional y los trajes populares en diferentes localidades de la región, siempre con una clara intencionalidad política de servicio al Régimen (Ortiz 2012), mientras que la indumen-

${ }^{17}$ Sobre la aportación de la provincia de Badajoz, véase Lemus (1991), y Valadés (2013) por lo que respecta a la de Cáceres. 


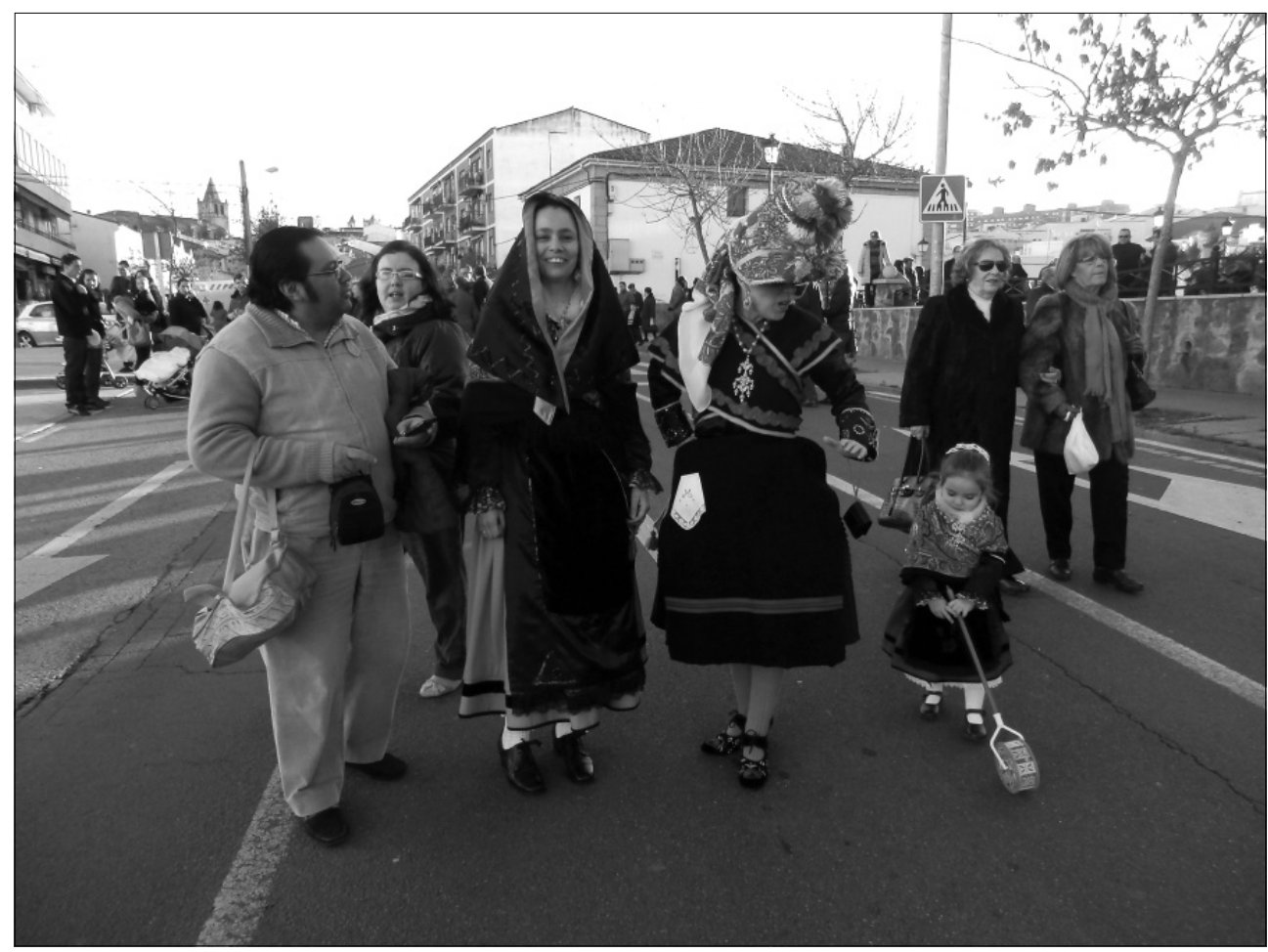

FIGURA 5.-Mujeres cacereñas ataviadas con trajes regionales. Romería de San Blas (Cáceres) 2013.

taria tradicional desaparece definitivamente del uso habitual. De ese proceso tenemos abundantes muestras gráficas, puesto que la indumentaria extremeña queda retratada en infinidad de ocasiones y soportes en sus dos versiones: una de ellas es la estereotipada del traje regional en las numerosas imágenes de todo tipo, publicitarias o documentales, que circulan identificando el traje extremeño, casi siempre el de Montehermoso, pero también los de las dos provincias. Tarjetas postales, grabados, calendarios o sellos de correos reproducen hasta la saciedad unas imágenes que vemos cómo van estandarizándose hasta llegar al icono canónico actual; entre ellas destacan los dibujos de Joan d'Ivori (Joan Vila i Pujol) en su obra Vestits tipics d'Espanya (1935), los de Vicente Viudes a partir de los trajes regalados por el régimen franquista a Eva Perón (1947) o los de Francisco López Rubio en el libro de Cecilio Barberán España, trajes regionales (1951), sin olvidar las postales de Ediciones Medina sobre dibujos de Elsi Gumier a mediados de los años cincuenta y por supuesto los sellos de correos aparecidos en 1967.

De todas aquellas imágenes deriva también la otra versión, la de los que van siendo aceptados como iconos verdaderos de los trajes populares locales, que en unos casos parten de prendas antiguas conservadas o de grabados y fotografías, pero en otros ya hemos visto que se inventan o se componen con prendas importadas de aquí y de allá; esto no impide que, por ejemplo, de la ciudad de Badajoz se presenten aho- 
ra un traje campero, otro de diario y otro de gala, o que aparezca el traje de Don Benito, que se hallaba perdido, incorporando el refajo de listas blancas y negras a que se refería Anderson. La tercera versión, la de la indumentaria tradicional que se vistió realmente y que muchas familias conservaban como herencia de sus antepasados, se puede estudiar a través de las pocas prendas que han llegado hasta nosotros, pero también en las numerosísimas imágenes, más o menos antiguas, que se han conservado, desde las publicadas en distintos medios hasta las fotografías familiares, realizadas en estudios o por las propias familias, que se guardan en las casas y que en los últimos años, van aflorando gracias a la publicación de una buena cantidad de historias locales. A través de esas imágenes puede verse cómo evolucionó la forma de vestir a lo largo del siglo XX, comprobándose casi siempre que hacia 1930 sólo las personas de más edad mantenían las formas tradicionales, aunque tras la guerra civil prácticamente esas prendas desaparecieron del uso diario para pasar a formar parte del repertorio del carnaval o de fiestas religiosas de distintos tipos.

En ese maremágnum de prendas y de imágenes vemos cómo la vestimenta ha sido y es utilizada como símbolo de la identidad grupal, de la región, de la provincia y del pueblo. Por ello, las pocas ocasiones en que hoy día se pueden ver personas vistiendo los trajes regionales o populares, especialmente niños, es en las diferentes fiestas que a lo largo y ancho de la región se celebran durante el año. Eventos como el Peropalo de Villanueva de la Vera, el Chíviri de Trujillo, la Romería de San Blas en Cáceres (Fig. 5) o la de la Virgen de los Remedios en Fregenal, de los Hitos en Alcántara o de Carrión en Alburquerque, que sirven en definitiva para reafirmar la conciencia de pertenencia a la comunidad, para reforzar la identidad, son el ámbito habitual en que, ya en el siglo XXI, aún podemos disfrutar de estas reliquias del pasado.

\section{BIBLIOGRAFÍA CITADA}

Anderson, R. M. 1951. Spanish Costume. Extremadura. Nueva York: Hispanic Society of America.

Anderson, R. M. 1957. Costumes painted by Sorolla in his provinces of Spain. Nueva York: Hispanic Society of America.

Anónimo. 1851. Recuerdos de un viage por España. Tomo III: Andalucía, Extremadura, Castilla la Nueva y Madrid. Madrid: Mellado.

Arnhold, A. 1986. "Lo tradicional no es de siempre", en Díaz Viana, L. (ed), Etnología y folklore en Castilla y León: 49-55. Salamanca: Junta de Castilla y León.

Barberán, C. 1951. España: trajes regionales. Madrid: Editora Nacional.

Barth, F. 1976. Los grupos étnicos y sus fronteras. La organización social de las diferencias culturales. México: Fondo de Cultura Económica.

Bazán de Huerta, M. 1991. Eulogio Blasco, 1890-1960. Cáceres: Diputación Provincial.

Blázquez Entonado, F. y de la Maya Retamar, G. 1992. "La Semana de Extremadura en la Escuela, proyecto didáctico de carácter singular". Campo Abierto. Revista de Educación 9: 329-342.

Calvo Buezas, T. 1993. "Otras identidades en España: el caso de Extremadura y de las minorías étnicas", en Ávila Palafox, R. y Calvo Buezas, T. (comp.), Identidades, nacionalismos y regiones: 319-340. México: Universidad de Guadalajara y Universidad Complutense de Madrid.

Calvo Buezas, T. 1996. "La identidad extremeña. Hacia la nueva imagen", en Castro Vicente, F. y otros (eds.), Identidad y fronteras culturales: Antropología y Museística. Actas del II Congreso de Historia de la Antropología Española: 53-70. Badajoz: Asociación de Psicología Extremadura.

Caro Baroja, J. 1990 [1969]. Ensayo sobre la literatura de cordel. Madrid: Istmo.

Carrafa, J. y Ribelles y Helip, J. 1825. Colección de trajes de España. Madrid: Real Calcografía. 
Champagny, C. de 1829. Album d'un soldat pendant la Campagne d'Espagne en 1823. París: Imprimerie de Cosson.

Díaz y Pérez, N. 1887. Extremadura (Badajoz y Cáceres). De la serie España, sus monumentos y artes, su naturaleza e historia. Barcelona: Estab. Tip. Editorial de Daniel Cortezo.

Esteva Fabregat, C. 1984. Estado, etnicidad y biculturalismo. Barcelona: Península.

García Ballesteros, Ma V.; J. Fernández Moreno; A. Hurtado Vinagre y V. Novillo González. 1998. La indumentaria tradicional de Extremadura. Cuadernos Populares, no $² 8$, Mérida: Editora Regional de Extremadura.

Gaviria, M.; Naredo, J. M. y Serna, J. (coords.). 1978. Extremadura saqueada. Recursos naturales y autonomía regional. París: Ruedo Ibérico.

Geertz, C. 2004 [1994]. Conocimiento local. Ensayos sobre la interpretación de las culturas. Barcelona: Paidós.

González Carballo, J. L.; Sierra Padilla, Ma G. y Esteban Hernández, R.. 2002. La materia optativa Cultura Extremeña: propuesta de desarrollo curricular y aplicación didáctica. Mérida: Consejería de Educación, Ciencia y Tecnología.

González Mena, M. Á. 1990. "Funciones y simbolismo de las artes textiles populares cacereñas". Revista de Estudios Extremeños XLVI (1): 9-86.

Guerrero Ramos, F. 1980. El pintor Juan Caldera. Cáceres: Diputación Provincial.

Gutiérrez, A. 1993. "Aportación para el estudio de la indumentaria española. Fotografías de J. Laurent, S. XIX", en Conferencia Internacional de colecciones y museos de indumentaria: 143-157. Madrid: Ministerio de Cultura.

Hernández Bermejo, M. Á. 1990. La familia extremeña en los tiempos modernos. Badajoz: Diputación Provincial.

Hobsbawm, E. 2002 [1983]. "Introducción: la invención de la tradición", en E. Hobsbawm y T. Ranger (eds.), La invención de la tradición: 7-21. Barcelona: Crítica.

Hoyos Sáinz, L. de y Hoyos Sancho, N. de. 1947. Manual de Folklore. La vida popular tradicional en España. Madrid: Revista de Occidente.

Hoyos Sancho, N. de. 1955. "El traje regional de Extremadura". Revista de Dialectología y Tradiciones Populares XI: $155-177$ y 353-385.

Hurtado, A. 1872. "Cáceres", en Las mujeres españolas, portuguesas y americanas. Tales como son en el hogar doméstico, en los campos, en las ciudades, en el templo, en los espectáculos, en el taller y en los salones: T. I. 161-175. Madrid: Imprenta y Librería de D. Miguel Guijarro.

Leach, E. 1981 [1978]. Cultura y comunicación. La lógica de la conexión de los símbolos. Madrid: Siglo XXI.

Legendre, M. 1927. Las Jurdes. Étude de Géographie Humaine. Burdeos: Bibliothèque de l'École des Hautes Études Hispaniques.

Lemus López, E. 1991. Extremadura y América: la participación regional en la Exposición IberoAmericana de 1929. Mérida: Editora Regional de Extremadura.

Lenaghan, P. 2004. In the lands of Extremadura. Ruth Matilda Anderson's photographs of Western Spain for the Hispanic Society. Madrid: Hispanic Society / MEIAC.

López Mondéjar, P. 1989. Las Fuentes de la Memoria. Fotografía y sociedad en la España del siglo XIX. Barcelona: Lunwerg Editores.

Marcos Arévalo, J. 1998. "La identidad extremeña. Reflexiones desde la Antropología social". Gazeta de Antropología 14. http://hdl.handle.net/10481/7542.

Marcos Arévalo, J. 2008. Objetos, sujetos e ideas (Bienes etnológicos y memoria social). Badajoz: Ayuntamiento.

Marcos Arévalo, J. y Guío Cerezo, Y. 1996. "Extremadura", en Fernández Montes, M. (coord.), Etnología de las Comunidades Autónomas: 333-373. Madrid: CSIC - Doce Calles.

Monje, R. 1847. "Una boda en Carrascalejo (Estremadura)". Semanario Pintoresco Español 4, 24 de enero: 25-28 y 5, 31 de enero: 35-36.

Montero Curiel, P. 2006. El extremeño. Madrid: Arco Libros.

Moreno Navarro, I. 2008 [1985]. "Etnicidad, conciencia de etnicidad y movimientos nacionalistas: aproximación al caso andaluz", en Moreno, I. (comp.), La identidad cultural de Andalucía. Aproximaciones, mixtificaciones, negacionismo y evidencias: 187-210. Sevilla: Centro de Estudios Andaluces. 
Muro Castillo, M. 2000. La fotografía en Extremadura, 1847-1951. Badajoz: MEIAC.

Ortiz Echagüe, J. 1933. España. Tipos y trajes. $4^{a}$ ed. Barcelona: Sociedad General de Publicaciones, S. A. Ortiz García, C. 1987. Luis de Hoyos Sáinz y la Antropología Española. Madrid: CSIC.

Ortiz García, C. 2012. "Folclore, tipismo y política. Los trajes regionales de la Sección Femenina de Falange", Gazeta de Antropología 28 (3). http://www.gazeta-antropologia.es/?p=1432

Palencia, I. de. 1926. The Regional Costumes of Spain. Their importance as a primitive expression of the aesthetic ideals of the nation. Madrid: Editorial Voluntad.

Pujadas Muñoz, J. J. 1993. Etnicidad. Identidad cultural de los pueblos. Madrid: Eudema.

Rodríguez Contreras, M. 1993. "Sobre la bandera de Extremadura", en Encuentros de bistoria de Extremadura y su didáctica: 345-346. Badajoz: Ministerio de Educación y Ciencia y CEP de Badajoz.

Sampelayo, Mํ. J. 1969. "Labor de la Sección Femenina en el resurgimiento del folklore español”, en Etnología y tradiciones populares (I Congreso Nacional de Artes y Costumbres Populares): 99-101. Zaragoza: Institución Fernando el Católico.

Sánchez Franco, Ma F. 2008. Indumentaria tradicional de la provincia de Cáceres. Recuerdo vivo. Cáceres: Diputación Provincial.

Santillana Pérez, M. 1992. La vida: nacimiento, matrimonio y muerte en el partido de Cáceres en el siglo XVIII. Cáceres: Institución Cultural el Brocense.

Testón Núñez, I. 1985. Amor, sexo y matrimonio en Extremadura. Badajoz: Universitas Editorial.

Thiesse, A.-M. 2001. La création des identités nationales. Europe XVIIIe - XXe siècle. París: Éditions du Seuil.

Valadés Sierra, J. M. 1994. "La indumentaria como símbolo regional. La tradición inventada en el caso del traje femenino de Montehermoson. Revista de Dialectología y Tradiciones Populares XLIX (1): 91-117.

Valadés Sierra, J. M. 1995. "El ritual y la construcción de la etnicidad en una comunidad de emigra-

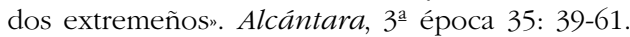

Valadés Sierra, J. M. 1996. "La tierra tira. Una aportación al conocimiento de los vínculos de los emigrados extremeños con sus pueblos de origen”. Revista de Estudios Extremeños LII (1): 165-197.

Valadés Sierra, J. M. 2011. "Vivir como un cura. El hogar de un clérigo acomodado en Extremadura al final del Antiguo Régimen". Etnicex. Revista de Estudios Etnográficos 3: 139-172.

Valadés Sierra, J. M. 2013. “La aportación cacereña al Pabellón de Extremadura en la Exposición Ibero Americana de Sevilla (1929)». Revista de Estudios Extremeños LXIX (3): 1811-1880.

Vega, J. 2002. "Ortiz Echagüe en las colecciones del Museo Nacional de Antropología", en José Ortiz Echagüe en las colecciones del Museo Nacional de Antropología: 17-68. Madrid: Ministerio de Educación, Cultura y Deporte.

Vega, J. 2005. "De la estampa a la fotografía: el traje regional y el simulacro de España", en Ortiz García, C.; Sánchez Carretero, C. y Cea Gutiérrez, A. (coords.), Maneras de mirar. Lecturas antropológicas de la fotografía: 61-82. Madrid: CSIC.

Vila i Pujol, J. (Joan d'Ivori). 1936. Vestits típics d'Espanya. Barcelona: Ed. Orbis.

Villalba Lava, M. 2009. El Fuero del Baylío como Derecho Foral de Extremadura. Mérida: Asamblea de Extremadura.

VV. AA. 1988. Extremadura como problema, Revista Alcántara. 3a época, 13-14. Cáceres: Institución Cultural El Brocense.

VV. AA. 1993. Viaje a Las Hurdes. El manuscrito inédito de Gregorio Marañón y las fotografías de la visita de Alfonso XIII. Madrid: El País / Aguilar.

VV. AA. 1999. Eugenio Hermoso. Badajoz: Diputación Provincial.

VV. AA. 2001. Adelardo Covarsí. Badajoz: Diputación Provincial.

Zarandieta Arenas, F. 2000. "Riqueza y consumo en la Baja Extremadura en el siglo XVII. Análisis a través de las cartas de dote». Historia Agraria. Revista de Agricultura e Historia Rural 21: 63-97.

Fecha de recepción: 7 de diciembre de 2012

Fecha de aceptación: 29 de agosto de 2013 